

\title{
Transactions
}

Cite this: Dalton Trans., 2011, 40, 1662

wWW.rsc.org/dalton

PAPER

\section{Access to new Janus head ligands: linking sulfur diimides and phosphanes for hemilabile tripodal scorpionates $\dagger$}

\author{
Margret M. Meinholz, ${ }^{a}$ Sushil K. Pandey, ${ }^{b}$ Stephan M. Deuerlein ${ }^{a}$ and Dietmar Stalke*a \\ Received 15th June 2010, Accepted 24th November 2010 \\ DOI: $10.1039 / \mathrm{codt00665c}$
}

Reactions of lithium dialkyl/phenyl phosphanylmethylides, RR'PCH(X)Li $\left(\mathrm{R}, \mathrm{R}^{\prime}=\mathrm{Me}, \mathrm{Et}, \mathrm{Ph}\right.$ and $\mathrm{R}=$ $\mathrm{Me}, \mathrm{R}^{\prime}=\mathrm{Ph} ; \mathrm{X}=\mathrm{H}$ or $\left.\mathrm{Me}\right)$, with sulfur diimides $\mathrm{S}\left(\mathrm{NR}^{\prime \prime}\right)_{2}\left(\mathrm{R}^{\prime \prime}={ }^{t} \mathrm{Bu}\right.$ or $\left.\mathrm{SiMe}_{3}\right)$ in an equimolar ratio yielded Janus head complexes with the structural motif $\left[\mathrm{Li}\left\{\mathrm{RR}^{\prime} \mathrm{PCH}(\mathrm{X}) \mathrm{S}\left(\mathrm{NR}^{\prime \prime}\right)_{2}\right\}\right]_{2}\left(\mathrm{R}^{\prime \prime}={ }^{t} \mathrm{Bu}, \mathrm{SiMe}_{3}\right)$. The basic core of these dimeric complexes is composed of a $(\mathrm{LiN})_{2}$ four-membered ring containing two four-coordinated lithium atoms. A lithium complex of the new Janus head ligand with another structural motif [TMEDA. $\left.\mathrm{Li}\left\{\mathrm{Ph}_{2} \mathrm{PCH}_{2} \mathrm{~S}\left(\mathrm{NSiMe}_{3}\right)_{2}\right\}\right]$ (6) could be isolated from the reaction of $\left[\mathrm{Ph}_{2} \mathrm{PCH}_{2} \mathrm{Li} \cdot \mathrm{TMEDA}\right]$ with $\mathrm{S}\left(\mathrm{NSiMe}_{3}\right)_{2}$. Two monomeric complexes $\left[\mathrm{Mg}\left\{\mathrm{Me}_{2} \mathrm{PCH}_{2} \mathrm{~S}\left(\mathrm{NR}^{\prime \prime}\right)_{2}\right\}_{2}\right](\mathbf{7}, \mathbf{8})$ were synthesised by a straightforward reaction of $\left[\mathrm{Li}\left\{\mathrm{Me}_{2} \mathrm{PCH}_{2} \mathrm{~S}\left(\mathrm{NR}^{\prime \prime}\right)_{2}\right\}_{2}\right]$ with $\mathrm{MgCl}_{2}$ in pentane. The magnesium atom is chelated by one phosphorus atom and two nitrogen atoms of each unit of the hemilabile ligand in a tripodal manner, leading to octahedral geometry around the magnesium cation. A complete analysis of $\left[\mathrm{Ph}_{2} \mathrm{PCH}_{2}\left(\mathrm{SNSiMe}_{3}\right)\left(\mathrm{HNSiMe}_{3}\right)\right](9)$ is also described in which one nitrogen atom of the imido moiety is protonated.

\section{Introduction}

Over the past few years our group has concentrated on heteroatomic-substituted multidentate ligand systems featuring two pendent arms and a second coordination site, which can also be referred to as "claw" ligands ${ }^{1}$ or scorpionates. ${ }^{2}$ Our principal strategy is to develop these ligands which bear coordination sites for both hard and soft metal centres in terms of the HSAB concept. ${ }^{3,4}$ If both coordination sites of the ligand point in opposite directions we call that a Janus head ligand. The functionalization of organodiimidosulfinates may be expanded by the introduction of an additional donor site in the backbone of the carbon substituent at the central sulfur atom. Ideally, this donor should be soft. By these means, simultaneous coordination of hard and soft metals in heterobimetallic complexes would be feasible, promoting their catalytic versatility.

If the length of the connecting clamp is large enough, both the apical and ancillary donors of the ambidentate ligands will be able to coordinate the same metal. In addition, such ambidentate systems will provide rigid and well defined coordination geometries leading to interesting chemical properties and reactivity patterns.

anstitut für Anorganische Chemie der Universität Göttingen, Tammannstraße 4, 37077, Göttingen, Germany. E-mail: dstalke@chemie.unigoettingen.de; Fax: +49-551-39-3459; Tel: +49-551-39-3000

${ }^{b}$ Department of Chemistry, University of Jammu, Jammu, 180 006, India $\dagger$ Electronic supplementary information (ESI) available: Experimental and crystallographic data, including the coordinates of all the species. CCDC reference numbers 779986-779988 and 779990-779995. For ESI and crystallographic data in CIF or other electronic format see DOI: $10.1039 / \mathrm{c} 0 \mathrm{dt} 00665 \mathrm{c}$
A literature survey shows that several tripodal ligand systems with group 15 elements as bridgehead atoms are known..$^{4-15}$

However, in most of these cases the metal is coordinated by the ancillary donors. Anionic ligands consisting of carbanions and heavier group 14 elements are another possibility for creating Janus head systems (Fig. 1). ${ }^{16}$

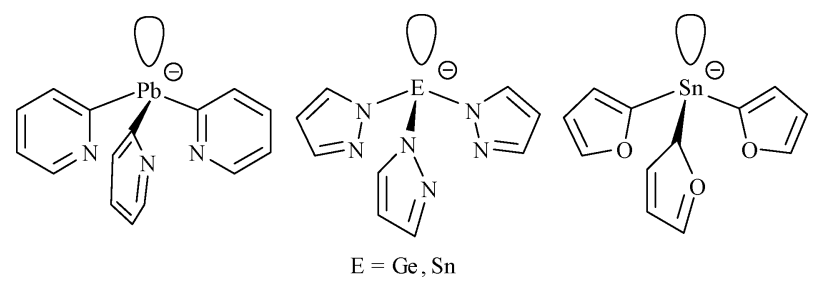

Fig. 1 Some tripodal ligand systems.

It is apparent from recent breakthroughs in this area that such ligands are about to be further developed and promising results are likely to occur. ${ }^{17}$ Multifunctional ligands with podand topology provide intrinsically well defined coordination geometries with interesting bonding aspects and reactivity patterns. There is growing interest in multidentate hemilabile ligand systems featuring dual functionality. The modification of classical chelating ligands to produce novel and fluxional multidentate systems has opened up an exciting area of research in the last few years. ${ }^{18}$ Janus head complexes are finding ever increasing applications in areas like heterolytic $\mathrm{H}_{2}$-splitting, ${ }^{19} \mathrm{NLO}$ (non linear optic) materials, ${ }^{20}$ organic transformation, ${ }^{21}$ asymmetric catalysis, ${ }^{22}$ cross coupling, ${ }^{11}$ microbial agents ${ }^{23}$ or light emitting diodes (LEDs). ${ }^{24}$ 
The complexes of magnesium metal with a ligand containing sulfur, nitrogen and phosphorus atoms may be promising precursors for semiconducting materials in the sol-gel or CVD process. ${ }^{25}$ Recently, the construction of (hetero)bimetallic or even multimetallic complexes using Janus head ligands became an interesting field of research since such complexes may serve as model compounds for one-dimensionally conducting polymers. ${ }^{16,25,26}$ We have already targeted group 15 element centred ligands, ${ }^{\text {a,b }}$ which are able to employ their substituent periphery in metal coordination, and reported on lithium sulfur ylides. ${ }^{27,28}$

The complex $\left[\left(\mathrm{H}_{5} \mathrm{C}_{3}\right) \mathrm{Ni}\left\{{ }^{t} \mathrm{Bu}_{2} \mathrm{PCH}_{2} \mathrm{~S}\left(\mathrm{NSiMe}_{3}\right)_{2}\right\}\right]$, has been reported in a patent as an active catalyst for the co-polymerization of ethylene with polar co-monomers without further study. ${ }^{29}$ Therefore we have inserted bis(tert-butyl)sulfur diimide into the $\mathrm{Li}-\mathrm{C}$ bond of organolithium species to link a sulfur diimide with a phosphanyl moiety to study the coordination geometry of the resulting ligand.

We report herein the synthesis, characterization and single crystal X-ray structure elucidation of $\left.\left[\mathrm{Li}\left\{\mathrm{RR} \mathrm{RCH}^{\prime} \mathrm{X}\right) \mathrm{S}\left(\mathrm{NR}^{\prime \prime}\right)_{2}\right\}\right]_{2}$ $\left(\mathrm{R}^{\prime \prime}={ }^{t} \mathrm{Bu}, \mathrm{X}=\mathrm{H}, \mathrm{RR}^{\prime}=\mathrm{Me}(\mathbf{1}) / \mathrm{Ph}(3), \mathrm{R}=\mathrm{Me}, \mathrm{R}^{\prime}=\right.$ $\mathrm{Ph}$ (5); $\mathrm{R}^{\prime \prime}=\mathrm{SiMe}_{3}, \mathrm{X}=\mathrm{H}, \mathrm{RR}^{\prime}=\mathrm{Me}(2) ; \mathrm{R}^{\prime \prime}=\mathrm{SiMe}_{3}$, $\mathrm{X}=\mathrm{Me}, \mathrm{RR}^{\prime}=\mathrm{Et}$ (4), [TMEDA.Li $\left.\left\{\mathrm{Ph}_{2} \mathrm{PCH}_{2} \mathrm{~S}\left(\mathrm{NSiMe}_{3}\right)_{2}\right\}\right]$ (6), $\left[\mathrm{Mg}\left\{\mathrm{Me}_{2} \mathrm{PCH}_{2} \mathrm{~S}\left(\mathrm{~N}^{t} \mathrm{Bu}\right)_{2}\right\}_{2}\right](7),\left[\mathrm{Mg}\left\{\mathrm{Me}_{2} \mathrm{PCH}_{2} \mathrm{~S}\left(\mathrm{NSiMe}_{3}\right)_{2}\right\}_{2}\right](\mathbf{8})$ and $\left[\mathrm{Ph}_{2} \mathrm{PCH}_{2}\left(\mathrm{SNSiMe}_{3}\right)\left(\mathrm{HNSiMe}_{3}\right)\right](\mathbf{9})+$

\# Single-crystal structural analysis: The X-ray data sets were collected at $100(2) \mathrm{K}$ on a Bruker TXS Mo rotating anode $(\mathbf{1}, \mathbf{3}, \mathbf{4}, \mathbf{7}(T=250 \mathrm{~K}), \mathbf{8 , 9})$ or an INCOATEC Mo micro source ${ }^{39}(\mathbf{2}, \mathbf{5}, \mathbf{6})$ with mirror-monochromated Mo- $\mathrm{K}_{\alpha}$ radiation $(\lambda=0.71073 \AA)$. The single crystals were mounted in inert oil under argon atmosphere by applying special cryo application techniques. ${ }^{40}$ Structures were solved by direct methods with SHELXS and refined by full-matrix least squares on $F^{2}$ for all data with SHELXL. ${ }^{41,42}$ Non-hydrogen atoms were refined with anisotropic displacement parameters. All $\mathrm{H}$ atoms were placed in calculated positions and refined using a "riding-model". $\left[\mathbf{L i}\left\{\mathbf{M e}_{2} \mathbf{P C} \mathbf{H}_{2} \mathbf{S}\left(\mathbf{N}^{t} \mathbf{B u}\right)_{2}\right\}\right]_{\mathbf{2}}(\mathbf{1}): \mathrm{C}_{22} \mathrm{H}_{52} \mathrm{~N}_{4} \mathrm{P}_{2} \mathrm{~S}_{2} \mathrm{Li}_{2}, \quad M=$ 512.62, triclinic, $P \overline{1}, a=9.4916(4) \AA, b=9.6726(4) \AA, c=18.7808(8) \AA$, $\alpha=98.772(1)^{\circ}, \beta=92.004(1)^{\circ}, \gamma=114.778(1)^{\circ}, V=1537.76(11) \AA^{3}$, $Z=2,27095$ reflections measured, 7923 independent reflections $\left(R_{\text {int }}=\right.$ $0.0191), 305$ parameters, $R_{1}$ (all data) $=0.0341, R_{1}[I>2 \sigma(I)]=0.0266$, $\mathrm{w} R_{2}$ (all data) $=0.0693, \mathrm{w} R_{2}[I>2 \sigma(I)]=0.0657, \mathrm{GoF}=1.054$, largest diff. peak and hole 0.433 and $-0.304 \mathrm{e}^{-3}$. [ $\mathbf{L i}\left\{\mathbf{M e}_{2} \mathbf{P C H}_{2} \mathbf{S}\left(\mathbf{N S i M e}_{3}\right)_{2}\right\} \mathbf{I}_{\mathbf{2}} \mathbf{( 2 )}$ : $\mathrm{C}_{18} \mathrm{H}_{52} \mathrm{~N}_{4} \mathrm{Si}_{4} \mathrm{P}_{2} \mathrm{~S}_{2} \mathrm{Li}_{2}, M=576.94$, triclinic, $P \overline{1}, a=10.2715(11) \AA, b=$ $10.356(11) \AA, c=10.4832(11) \AA, \alpha=68.636(1)^{\circ}, \beta=65.728(1)^{\circ}, \gamma=$ $60.990(1)^{\circ}, V=869.77(16) \AA^{3}, Z=1,21105$ reflections measured, 3546 independent reflections $\left(R_{\text {int }}=0.0145\right), 153$ parameters, $R_{1}($ all data $)=$ $0.0236, R_{1}[I>2 \sigma(I)]=0.0216, \mathrm{w} R_{2}$ (all data) $=0.0619, \mathrm{w} R_{2}[I>$ $2 \sigma(I)]=0.0607, \mathrm{GoF}=0.861$, largest diff. peak and hole 0.314 and $-0.223 \mathrm{e}^{-3} \cdot\left[\mathbf{L i}\left\{\mathbf{P h}_{2} \mathbf{P C H} \mathbf{H}_{2} \mathbf{S}\left(\mathbf{N}^{t} \mathbf{B u}\right)_{2}\right\} \mathbf{l}_{\mathbf{2}} \mathbf{( 3 )}: \mathrm{C}_{42} \mathrm{H}_{60} \mathrm{~N}_{4} \mathrm{P}_{2} \mathrm{~S}_{2} \mathrm{Li}_{2}, M=760.91\right.$, triclinic, $P \overline{1}, a=9.6236(11) \AA, b=10.1512(12) \AA, c=11.3253(13) \AA$, $\alpha=73.936(2)^{\circ}, \beta=84.728(2)^{\circ}, \gamma=88.960(2)^{\circ}, V=1058.7(2) \AA^{3}, Z=1$, 25994 reflections measured, 5259 independent reflections $\left(R_{\text {int }}=0.0399\right)$, 241 parameters, $R_{1}$ (all data) $=0.0564, R_{1}[I>2 \sigma(I)]=0.0391, \mathrm{w} R_{2}$ (all data) $=0.1026, \mathrm{w} R_{2}[I>2 \sigma(I)]=0.0976, \mathrm{GoF}=1.054$, largest diff. peak and hole 0.391 and $-0.381 \mathrm{eA}^{-3}$. [ $\left.\mathbf{L i}\left\{\mathbf{E t}_{2} \mathbf{P C H}(\mathbf{M e}) \mathbf{S}\left(\mathbf{N S i M e}_{3}\right)_{2}\right\}\right]_{2}(\mathbf{4})$ : $\mathrm{C}_{24} \mathrm{H}_{64} \mathrm{~N}_{4} \mathrm{Si}_{4} \mathrm{P}_{2} \mathrm{~S}_{2} \mathrm{Li}_{2}, M=661.09$, triclinic, $P \overline{1}, a=10.6002(6) \AA, b=$ $10.635(1) \AA, c=10.7744(6) \AA, \alpha=100.785(1)^{\circ}, \beta=117.366(1)^{\circ}, \gamma=$ 103.446(1) $, V=986.48(12) \AA^{3}, Z=1,39887$ reflections measured, 4676 independent reflections $\left(R_{\text {int }}=0.0146\right), 181$ parameters, $R_{1}$ (all data) $=0.0299, R_{1}[I>2 \sigma(I)]=0.0277, \mathrm{w} R_{2}$ (all data) $=0.0768, \mathrm{w} R_{2}$ $[I>2 \sigma(I)]=0.0747, \mathrm{GoF}=1.068$, largest diff. peak and hole 0.686 and $-0.453 \mathrm{e}^{-3}$. $\left[\mathbf{L i}\left\{\mathbf{P h}(\mathbf{M e}) \mathbf{P C H} \mathbf{H}_{2} \mathbf{S}\left(\mathbf{N}^{t} \mathbf{B u}\right)_{2}\right\} \mathbf{l}_{\mathbf{2}}(\mathbf{5}): \mathrm{C}_{32} \mathrm{H}_{56} \mathrm{~N}_{4} \mathrm{P}_{2} \mathrm{~S}_{2} \mathrm{Li}_{2}, M=\right.$ 636.75, monoclinic, $P 2_{1} / c, a=10.5006(14) \AA, b=20.753(3) \AA, c=$ 8.5699(11) ̊, $\alpha=\gamma=90^{\circ}, \beta=97.279(2)^{\circ}, V=1852.5(4) \AA^{3}, Z=2$, 39157 reflections measured, 3784 independent reflections $\left(R_{\text {int }}=0.0274\right)$, 197 parameters, $R_{1}$ (all data) $=0.0325, R_{1}[I>2 \sigma(I)]=0.0305, \mathrm{w} R_{2}$ (all data) $=0.0788, \mathrm{w} R_{2}[\mathrm{I}>2 \sigma(\mathrm{I})]=0.0778, \mathrm{GoF}=1.050$, largest diff. peak and hole 0.409 and $-0.247 \mathrm{e}^{-3}$.[TMEDA $\cdot \mathbf{L i}\left\{\mathbf{P h}_{2} \mathbf{P C H}_{2} \mathbf{S}\left(\mathbf{N S i M e}_{3}\right)_{2}\right\}$ ]

\section{Results and discussion}

The linkage of sulfurdiimide and phosphane in order to gain access to a new type of Janus head ligand is achieved by an equimolar reaction of lithium dialkyl/phenyl phosphanylmethanide, RR'PCH(X)Li $\left(\mathrm{RR}^{\prime}=\mathrm{Me}, \mathrm{X}=\mathrm{H}(\mathbf{1}, \mathbf{2})\right.$; $\mathrm{RR}^{\prime}=$ $\mathrm{Ph}, \mathrm{X}=\mathrm{H}$ (3); R = Et, $\mathrm{X}=\mathrm{Me}(4) ; \mathrm{R}=\mathrm{Me}, \mathrm{R}^{\prime}=\mathrm{Ph}, \mathrm{X}=\mathrm{H}$ (5)) with bis(trimethylsilyl)sulfur diimide, $\mathrm{S}\left(\mathrm{NSiMe}_{3}\right)_{2}$, or bis(tertbutyl)sulfur diimide, $\mathrm{S}\left(\mathrm{N}^{t} \mathrm{Bu}\right)_{2}$, in $n$-pentane under anhydrous and inert gas conditions (Scheme 1).

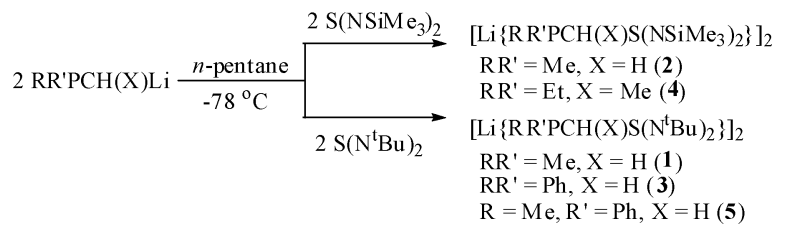

Scheme 1

Compounds 1-5 were obtained as white solids. The elemental analyses were found to be consistent with the molecular formulae.

Compound 1 crystallizes from $n$-pentane as colourless plates in the triclinic space group $P \overline{1}$ A dimer is formed owing to the inadequate bite of the ligand to the small lithium cation (Fig. 2). The $\mathrm{Me}_{2} \mathrm{P}$-sidearm is not coordinating to the already $\mathrm{SN}_{2}$-complexed lithium atom but to that of the second molecule. The main core of the system is a $(\mathrm{LiN})_{2}$ four-membered ring with both the lithium atoms forming three $\mathrm{N}$ - and one P-contact each.

One nitrogen atom of each ligand unit is coordinated to both lithium atoms while the second coordinates just the lithium atom of one half of the dimer (Li1-N1/Li2-N4). The phosphorus coordination to that lithium atom (Li1-P2/Li2-P1) provides additional stability to the complex (Fig. 3). Both halves of the dimer show almost no differences in bond lengths and angles. All S-N distances (1.6144(9)-1.6351(9) Å) are slightly shorter than an

(6): $\mathrm{C}_{27.5} \mathrm{H}_{52} \mathrm{~N}_{4} \mathrm{Si}_{2}$ PSLi, $M=564.89$, monoclinic, $C 2 / c, a=33.944(5) \AA$, $b=9.5352(13) \AA, c=21.921(3) \AA, \alpha=\gamma=90^{\circ}, \beta=101.895(3)^{\circ}, V=$ 6942.4(17) $\AA^{3}, Z=8,48696$ reflections measured, 6847 independent reflections $\left(R_{\text {int }}=0.0632\right), 441$ parameters, 16 restraints, $R_{1}$ (all data) $=$ $0.0505, R_{1}[I>2 \sigma(I)]=0.0368, \mathrm{w} R_{2}$ (all data) $=0.0942, \mathrm{w} R_{2}[I$ $>2 \sigma(I)]=0.0871, \mathrm{GoF}=1.041$, largest diff. peak and hole 0.348 and $-0.245 \mathrm{e}^{-3}$. $\left[\mathbf{M g}\left\{\mathbf{M e}_{2} \mathbf{P C H}_{2} \mathbf{S}\left(\mathbf{N}^{t} \mathbf{B u}\right)_{2}\right\}_{2}\right](7): \mathrm{C}_{22} \mathrm{H}_{52} \mathrm{~N}_{4} \mathrm{P}_{2} \mathrm{~S}_{2} \mathrm{Mg}, M=$ 523.07, orthorhombic, $F d d 2, a=37.169(8) \AA, b=10.175(2) \AA, c=$ 16.851(4) $\AA, V=6373(2) \AA^{3}, Z=8,21122$ reflections measured, 3270 independent reflections, $R_{\text {int }}=0.0407,180$ parameters, $R_{1}$ (all data) $=$ $0.0467, R_{1}[I>2 \sigma(I)]=0.0444, \mathrm{w} R_{2}$ (all data) $=0.1147, \mathrm{w} R_{2}[I>$ $2 \sigma(I)]=0.1137, \mathrm{GoF}=1.183$, largest diff. peak and hole 0.228 and $-0.212 \mathrm{e}^{-3} \cdot\left[\mathbf{M g}\left\{\mathbf{M e}_{2} \mathbf{P C H} \mathbf{H}_{2} \mathbf{S}\left(\mathrm{NSiMe}_{3}\right)_{2}\right\}_{2}\right] \mathbf{( 8 )}: \mathrm{C}_{18} \mathrm{H}_{52} \mathrm{~N}_{4} \mathrm{Si}_{4} \mathrm{P}_{2} \mathrm{~S}_{2} \mathrm{Mg}, M=$ 587.37, monoclinic, $P 2_{1} / n, a=10.2563(5) \AA, b=17.8142(8) \AA, c=$ 19.2917(9) $\AA, \alpha=\gamma=90^{\circ}, \beta=99.273(1)^{\circ}, V=3478.7(3) \AA^{3}, Z=4$, 156125 reflections measured, 9326 independent reflections $\left(R_{\text {int }}=0.0192\right)$, 296 parameters, $R_{1}$ (all data) $=0.0238, R_{1}[I>2 \sigma(I)]=0.0213, \mathrm{w} R_{2}$ (all data) $=0.0630, \mathrm{w} R_{2}[I>2 \sigma(I)]=0.0612$, GoF $=1.019$, largest diff. peak and hole 0.286 and $-0.263 \mathrm{e}^{-3} \cdot \mathbf{P h}_{2} \mathbf{P C H}_{2}\left(\mathbf{S N S i M e}_{3}\right)\left(\mathbf{H N S i M e}_{3}\right)$ (9): $\mathrm{C}_{19} \mathrm{H}_{31} \mathrm{~N}_{2} \mathrm{Si}_{2} \mathrm{PS}, M=406.67$, monoclinic, $P 2_{1} / n, a=12.9937(7) \AA, b=$ 9.9367(6) $\mathrm{A}, c=18.1145(1) \AA, \alpha=\gamma=90^{\circ}, \beta=99.843(1)^{\circ}, V=2304.4(2) \AA^{3}$, $Z=4$, 43786 reflections measured, 5491 independent reflections $\left(R_{\text {int }}=\right.$ $0.016), 235$ parameters, $R_{1}$ (all data) $=0.0289, R_{1}[I>2 \sigma(I)]=0.0278, \mathrm{w} R_{2}$ (all data $)=0.0767, \mathrm{w}_{2}[I>2 \sigma(I)]=0.0757, \mathrm{GoF}=1.052$, largest diff. peak and hole 0.596 and $-0.340 \mathrm{e}^{-3}$.Crystallographic data (excluding structure factors) for the structures reported in this paper have been deposited with the Cambridge Crystallographic Data Centre as supplementary publication no. CCDC 779986 (1), 779990 (2), 779987 (3), 779991 (4), 779992 (5), 779993 (6), 779988 (7), 779994 (8) and 779995 (9). 


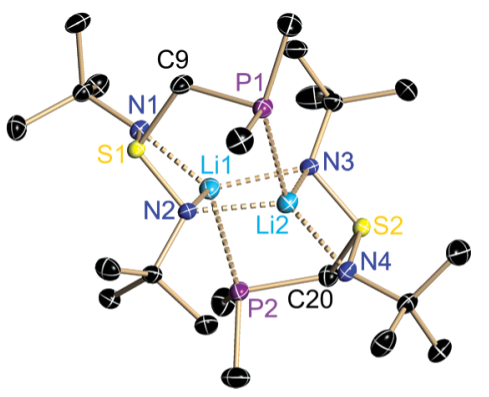

Fig. 2 Molecular structure of $\left[\mathrm{Li}\left\{\mathrm{Me}_{2} \mathrm{PCH}_{2} \mathrm{~S}\left(\mathrm{~N}^{t} \mathrm{Bu}\right)_{2}\right\}\right]_{2}(\mathbf{1})$ in the crystal. Anisotropic displacement parameters are depicted at the $50 \%$ probability level, hydrogen atoms are omitted for clarity. Selected bond lengths $[\AA ̊]$ and angles $\left[^{\circ}\right]$ : S1-N1 1.6144(9), S1-N2 1.6351(9), S1-C9 1.8406(11), P1-C9 1.8403(11), Li1-N1 1.939(2), Li1-N2 2.398(2), Li2-P1 2.6425(19); N1-S1-N2 104.74(5), N1-S1-C9 106.38(5), N2-S1-C9 100.60(5), Li1-N2-Li2 69.23(7), N1-Li1-N2 71.93(7), N2-Li2-P1 76.79(6).

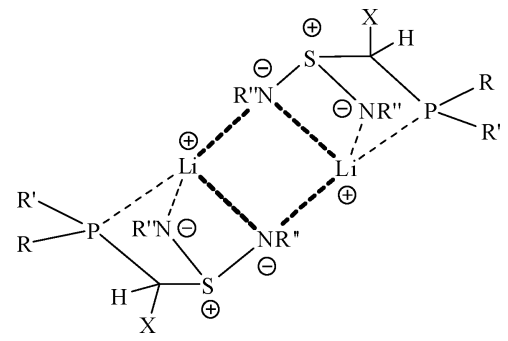

Fig. 3 Generic line drawing of complexes 1-5 (for R, R', R" and X see Scheme 1).

average sulfur-nitrogen single bond $(1.69 \AA)$ and are in the range of other alkyl diimidosulfinates $(1.598-1.657 \AA){ }^{30}$

The $\mathrm{S}-\mathrm{C}$ bond lengths match with standard $\mathrm{S}-\mathrm{C}_{\mathrm{sp} 3}$ single bonds $(1.83 \AA) .{ }^{30}$ Hence, S1 is surrounded by single bonds only and adopts the tetrahedral environment akin to an $\mathrm{sp}^{3}$-hybridized atom. The N1-S1-N2 $\left(104.74(5)^{\circ}\right), \mathrm{N} 1-\mathrm{S} 1-\mathrm{C} 9\left(106.38(5)^{\circ}\right)$ and $\mathrm{N} 2-\mathrm{S} 1-\mathrm{C} 9\left(100.60(5)^{\circ}\right)$ angles are reduced with respect to the ideal tetrahedral angle. This is according to the VSEPR theory, because the stereochemically active lone pair at $\mathrm{S} 1$ takes up most space. $\mathrm{Li} 1-\mathrm{N} 1$ and $\mathrm{Li} 2-\mathrm{N} 2$ are in the typical range of $\mathrm{Li}-\mathrm{N}$ bonds

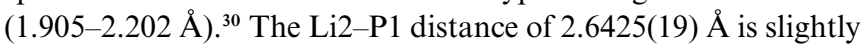
longer than the average $\mathrm{Li}-\mathrm{P}$ distances in $\mathrm{Li}(\mathrm{P}-\mathrm{C}-\mathrm{C}=\mathrm{N})$ systems $(2.520 \AA) .{ }^{18}$ The acute N2-Li2-P1 angle of $76.79(6)^{\circ}$ is typical for such systems $\left(73.10-87.35^{\circ}\right) .^{28}$

It is easily possible to modify the ligand structure by introducing different substituents at the sulfur atom. $\left[\mathrm{Li}\left\{\mathrm{Me}_{2} \mathrm{PCH}_{2} \mathrm{~S}\left(\mathrm{NSiMe}_{3}\right)_{2}\right\}\right]_{2}$ (2) crystallizes from $n$-pentane as colourless blocks in the triclinic space group $P \overline{1}$ (Fig. 4). The main core of the system consists of a $(\mathrm{LiN})_{2}$ heteroatomic ring just like in complex 1. All S-N bond distances (1.6031(10)$1.621(10) \AA$ ) are slightly shorter than an average sulfur-nitrogen single bond (1.69 $\AA$ ) ${ }^{30}$ Probably there is the presence of $\mathrm{S}^{+}-\mathrm{N}^{-}$ electrostatic bond shortening as described for many $\mathrm{S}-\mathrm{N}$ systems from experimental and theoretical charge density investigations. ${ }^{31}$ The N1-S1-N2 $\left(105.89(5)^{\circ}\right), \mathrm{N} 1-\mathrm{S} 1-\mathrm{C} 1\left(102.66(6)^{\circ}\right)$ and N2-S1$\mathrm{C} 1\left(101.53(5)^{\circ}\right)$ bond angles are similar to 1 . The shared lithium coordination of $\mathrm{N} 2$ leads to longer $\mathrm{Li}-\mathrm{N}$ distances (Li1-N2 2.315(2) and Li1'-N2 $2.029 \AA)$ compared to Li1-N1 (1.989(2) ̊). $\mathrm{Li} 1-\mathrm{N} 1$ and $\mathrm{Lil}^{\prime}-\mathrm{N} 2$ are in the typical range of $\mathrm{Li}-\mathrm{N}$ bonds $(1.905-2.202 \AA){ }^{30}$ but Li1 seems to be weakly coordinated to N2.

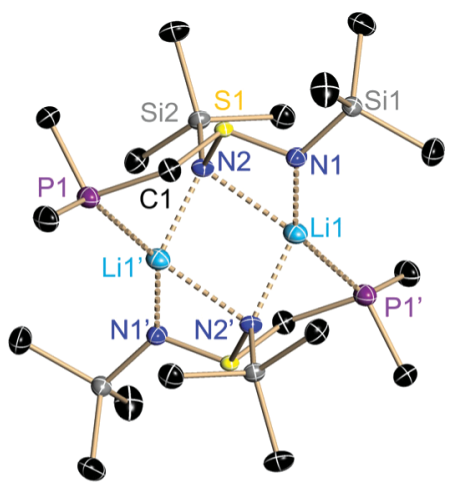

Fig. 4 Molecular structure of $\left[\mathrm{Li}\left\{\mathrm{Me}_{2} \mathrm{PCH}_{2} \mathrm{~S}\left(\mathrm{NSiMe}_{3}\right)_{2}\right\}\right]_{2}$ (2) in the crystal. Anisotropic displacement parameters are depicted at the $50 \%$ probability level, hydrogen atoms are omitted for clarity. Atoms labeled with prime $(')$ are symmetry equivalents generated by $1-x, 2-y$, $1-z$. Selected bond lengths $[\AA]$ and angles $\left[{ }^{\circ}\right]$ : S1-N1 1.6031(10), S1-N2 1.6221(10), S1-C1 1.8286(12), P1-C1 1.8406(13), Li1-N1 1.989(2), Li1-N2 2.315(2), Li1-P1' 2.655(2); N1-S1-N2 105.89(5), N1-S1-C1 102.66(6), N2-S1-C1 101.53(5), Li1-N2-Li1' 80.96(9), N1-Li1-N2 73.00(8), N2-Li1'-P1 79.63(7).

Inspection of the molecular structures of $\mathbf{1}$ and $\mathbf{2}$ reveals that the $\mathrm{N}_{2} \mathrm{SCP}$ ligand is indeed tridentate. Although the bite of the ligand system is not optimized for lithium cations, the complexes formed are surprisingly stable.

The complex $\left[\mathrm{Li}\left\{\mathrm{Ph}_{2} \mathrm{PCH}_{2} \mathrm{~S}\left(\mathrm{~N}^{t} \mathrm{Bu}\right)_{2}\right\}\right]_{2}$ (3) was synthesized by equimolar reaction of lithio(diphenylphosphino)methanetetramethylethylenediamine, $\quad\left[\mathrm{Ph}_{2} \mathrm{PCH}_{2} \mathrm{Li}\right.$.TMEDA $]$ with $\mathrm{S}\left(\mathrm{N}^{\prime} \mathrm{Bu}\right)_{2}$ in $n$-pentane to modify the substituents at the phosphorus atom. It was crystallized from toluene, yielding colourless crystals in the space group $P \overline{1}$ with half a molecule in the asymmetric unit.

The main core of the system also consists of a $(\mathrm{LiN})_{2}$ fourmembered heteroatomic ring (Fig. 5). The structural characteristics of $\mathbf{3}$ are thus akin to complexes $\mathbf{1}$ and $\mathbf{2}$. Nevertheless the molecule has a centre of inversion. The bond lengths and angles of $\mathbf{3}$ fall within the expected ranges.

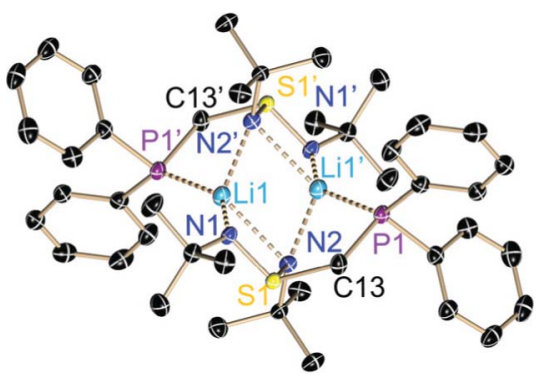

Fig. 5 Molecular structure of $\left[\mathrm{Li}\left\{\mathrm{Ph}_{2} \mathrm{PCH}_{2} \mathrm{~S}\left(\mathrm{~N}^{t} \mathrm{Bu}\right)_{2}\right\}\right]_{2}(3)$ in the crystal. Anisotropic displacement parameters are depicted at the $50 \%$ probability level, hydrogen atoms are omitted for clarity. Atoms labeled with prime (') are symmetry equivalents generated by $1-x, 1-y,-z$. Selected bond lengths $[\AA]$ and angles $\left[^{\circ}\right]$ : S1-N1 1.6120(14), S1-N2 1.6925(14), S1-C13 1.8412(17), P1-C13 1.8404(17), Li1-N1 1.959(3), Li1-N2 2.318(3), Li1-P1 2.657(3); N1-S1-N2 104.15(7), N1-S1-C13 106.45(8), N2-S1-C13 101.29(7), Li1-N2-S1 84.68(9), N1-Li1-N2 72.88(10), N1-Li1-P1 147.48(14), N2-Li1-P1 117.31(12). 
In order to obtain more insight into the coordinative behavior of the new $\mathrm{N}_{2} \mathrm{SCP}$ system, further modifications at the P,S bridging carbon atom were introduced. The compound $\left[\mathrm{Li}\left\{\mathrm{Et}_{2} \mathrm{PCH}-\right.\right.$ $\left.\left.(\mathrm{Me}) \mathrm{S}\left(\mathrm{NSiMe}_{3}\right)_{2}\right\}\right]_{2}$ (4) is isostructural to 2 (Fig. 6). It is also obtained as a dimer and the main core of the system is a $(\mathrm{LiN})_{2}$ four-membered ring with both the lithium atoms displaying four contacts to the donor atoms of each ligand (Fig. 5). Different to $\mathbf{2}$, in $\mathbf{4}$ chirality is introduced at the P,S bridging methylene carbon atom C7. Due to the center of inversion in the middle of the $(\mathrm{LiN})_{2}$ four-membered ring $\mathbf{4}$ crystallizes as a racemate. The $\mathrm{S}-\mathrm{N}$ bond distances are almost equal to 2 and are 1.5906(10) $\AA$ for S1-N1 and 1.6235(10) $\AA$ for $\mathrm{S} 1-\mathrm{N} 2$, respectively. The two $\left(\mathrm{SN}_{2}\right)$ units are inclined by $116.9^{\circ}$ with respect to the $(\mathrm{LiN})_{2}$ ring and the ethyl phosphane moieties reside on opposite sides of the $\left(\mathrm{SN}_{2}\right)$ planes. Thus, the steric strain between the trimethylsilyl groups is minimized. The S-C bond length of 1.8300(12) A exactly matches the value reported for the presence of a standard $\mathrm{S}-\mathrm{C}_{\mathrm{sp} 3}$ single bond. ${ }^{30}$ So, a tetrahedral environment around the sulfur atom is assumed. The N1-S1-N2 (104.22(5) $\left.{ }^{\circ}\right), \mathrm{N} 1-\mathrm{S} 1-\mathrm{C} 7\left(102.57(6)^{\circ}\right)$ and $\mathrm{N} 2-\mathrm{S} 1-\mathrm{C} 7\left(102.80(6)^{\circ}\right)$ angles are similar to 2 . It is noteworthy that the $\mathrm{Li}-\mathrm{N}$ bond distances in $\mathbf{4}$ differ less from each other than in 2. The bond distance for Li1-N2 (2.219(2) $\AA$ ) is larger compared to Li1-N1 (2.028(2) $\AA$ ) since N2 is coordinated to both the lithium atoms. However, the Li1-N1 and Li1-N2 bond distances are in the typical range of $\mathrm{Li}-\mathrm{N}$ bonds as described for compound 2 . The N2-Li1'-P1 angle of $83.25(7)^{\circ}$ is less acute in $\mathbf{4}$ compared to $\mathbf{2}$, due to the bulkier groups on the phosphorus atom.

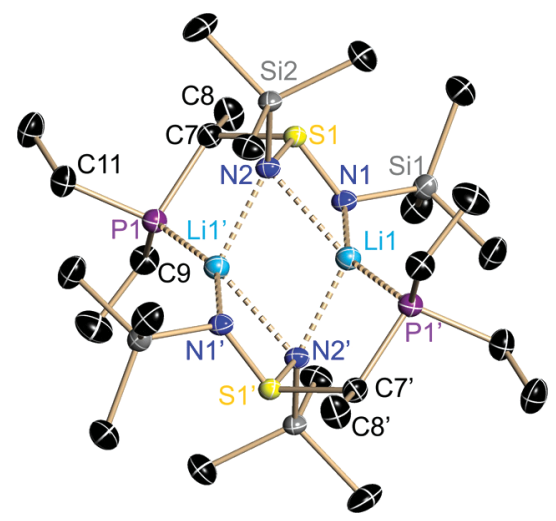

Fig. 6 Molecular structure of $\left[\mathrm{Li}\left\{\mathrm{Et}_{2} \mathrm{PCH}(\mathrm{Me}) \mathrm{S}\left(\mathrm{NSiMe}_{3}\right)_{2}\right\}\right]_{2}$ (4) in the crystal. Anisotropic displacement parameters are depicted at the 50\% probability level, hydrogen atoms are omitted for clarity. Atoms labeled with prime $(')$ are symmetry equivalents generated by $1-x, 2-y$, $1-z$. Selected bond lengths $[\AA ̊]$ and angles $\left[{ }^{\circ}\right]$ : S1-N1 1.5906(10), S1-N2 1.6235(10), S1-C7 1.8300(12), P1-C7 1.8682(13), Li1-N1 2.028(2), Li1-N2 2.219(2), Li1'-P1 2.622(2); N1-S1-N2 104.22(5), N1-S1-C7 106.57(6), N2-S1-C7 102.80(6), Li1'-N2-Li1 69.46(10), N1-Li1-N2 73.19(8), N2-Li1'-P1 83.25(7).

From the NMR spectra of $\mathbf{1 - 4}$ in solution it is obvious that the complexes show a dynamic behaviour different to the solid state. Both the ${ }^{7} \mathrm{Li}\left\{{ }^{1} \mathrm{H}\right\}$ and ${ }^{31} \mathrm{P}\left\{{ }^{1} \mathrm{H}\right\}$ NMR spectra reveal a coupling between two lithium atoms and one phosphorus atom and vice versa (septet in ${ }^{31} \mathrm{P}$ and a triplet in the ${ }^{7} \mathrm{Li} \mathrm{NMR}$ ). This can only be rationalized with a flipping $\mathrm{Li}-\mathrm{P}$-bond and on average the contact of a single phosphorus atom to two lithium atoms in solution
(Fig. 7). Similar dynamic behaviour has already been observed in other systems. ${ }^{32}$

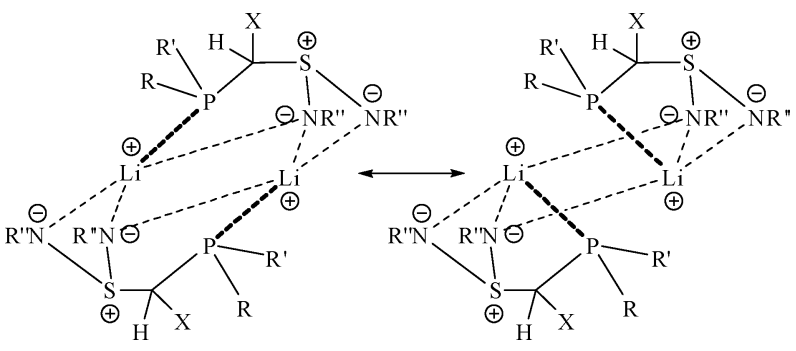

Fig. 7 Dynamic behaviour of complexes 1-5 in solution.

This hypothesis can be proven by the $\mathrm{Li}-\mathrm{P}$ coupling constants of approximately $19 \mathrm{~Hz}$ and the ${ }^{13} \mathrm{C}\left\{{ }^{1} \mathrm{H}\right\}$ NMR spectra of $\mathbf{3}$. The phenyl carbon atoms show various multiplets, whose structure can only be explained if both phosphorus atoms are coupled to each other and thus influence the carbon atoms in the rings. With phosphorus decoupling, however, those multiplets change into singlets.

The NMR spectra of $\mathbf{4}$ show a signal doubling which is due to the two diastereomers that are present in solution since $\mathrm{C} 7$ and $\mathrm{C}^{7}$ are stereocentres. The ${ }^{31} \mathrm{P}\left\{{ }^{1} \mathrm{H}\right\}$ spectrum for example shows two septets at -30.74 and $-27.34 \mathrm{ppm}$. Consequently, the ${ }^{1} \mathrm{H}$ and ${ }^{13} \mathrm{C}\left\{{ }^{1} \mathrm{H}\right\}$ spectra are even more complicated, as the alkyl signals lie very close to each other and are therefore overlaid.

Another possibility to generate a stereocentre in the ligand is to introduce a phosphorus side-arm with two different P-bound substituents. $\left[\mathrm{Li}\left\{\mathrm{Ph}(\mathrm{Me}) \mathrm{PCH}_{2} \mathrm{~S}\left(\mathrm{~N}^{t} \mathrm{Bu}\right)_{2}\right\}\right]_{2}(5)$ crystallizes from $n$ pentane in the monoclinic space group $P 2_{1} / \mathrm{c}$. Compound $\mathbf{5}$ is also obtained as a dimer and the main core of the system is the known $(\mathrm{LiN})_{2}$ four-membered ring. Most of the overall structural features are similar to those in $\mathbf{1 - 4}$. Due to the centre of inversion in the middle of the $(\mathrm{LiN})_{2}$ heteroatomic ring, $\mathbf{5}$ as well as $\mathbf{4}$ crystallizes as a racemate. The solid state structure is shown in Fig. 8.

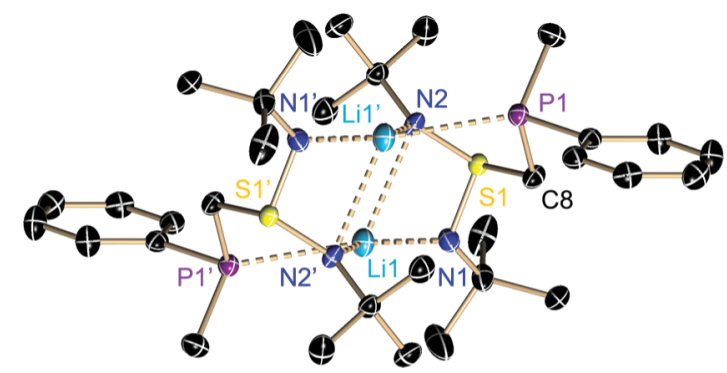

Fig. 8 Molecular structure of $\left[\mathrm{Li}\left\{\mathrm{Ph}(\mathrm{Me}) \mathrm{PCH}_{2} \mathrm{~S}\left(\mathrm{~N}^{t} \mathrm{Bu}\right)_{2}\right\}\right]_{2}$ (5) in the crystal. Anisotropic displacement parameters are depicted at the $50 \%$ probability level, hydrogen atoms are omitted for clarity. Atoms labeled with prime (') are symmetry equivalents generated by $2-x, 2-y, 2-z$. Selected bond lengths $[\AA]$ and angles $\left[{ }^{\circ}\right]$ : S1-N1 1.6107(11), S1-N2 1.6278(11), S1-C8 1.8398(13), P1-C8 1.8463(14), Li1-N1 1.957(3), Li1-N2 2.506(3), Li1'-P1 2.644(2); N1-S1-N2 105.68(6), N1-S1-C8 104.97(6), N2-S1-C8 98.81(6), Li1'-N2-Li1 69.23(7), N1-Li1-N2 76.86(11), N2-Li1'-P1 $76.66(7)$.

The $\mathrm{S}-\mathrm{N}$ bond distances are almost equal and lie in the range of 1.6107(11)-1.6278(11) $\AA$. The two $\left(\mathrm{SN}_{2}\right)$ units are tilted by $134.4^{\circ}$ with respect to the $(\mathrm{LiN})_{2}$ ring with the phosphane moiety residing on opposite sides of the $\left(\mathrm{SN}_{2}\right)$ planes, which is due to the different 
steric situation in 5 compared to 4 . The N1-S1-N2 $\left(105.68(6)^{\circ}\right)$ and $\mathrm{N} 1-\mathrm{S} 1-\mathrm{C} 8\left(104.97(6)^{\circ}\right)$ angles are almost in the same range as for compounds 2 and 4 . However, the N2-S1-C8 angle of 98.81(6) is slightly more acute than in $\mathbf{2}$ and $\mathbf{4}$. The acute N2-Li1-P1 angle of $76.66(7)^{\circ}$ is known for such systems $\left(73.10-87.35^{\circ}\right){ }^{28}$ however, this angle is the most acute among compounds $\mathbf{1 - 4}$.

The NMR spectra show a signal doubling that is due to two diastereomers which are present in solution, according to compound 4. In solution the phenyl rings can be arranged like in the solid state ('trans') or the phosphorus side-arm can rotate about the $\mathrm{S}-\mathrm{C}$ bond. As a result both phenyl rings are on the same side of the molecule ('cis'). Both diastereomers have very similar chemical shifts and their NMR signals are therefore overlaid. Thus it is impossible to assign specific shifts to one specific diastereomer, although it can be assumed that the trans isomer prevails as it reduces steric strain in the ligand. Integration of the $\mathrm{PCH}_{3}$ signals shows a ratio of 1 to 0.75 for trans to cis. As in all compounds of this type, the $\mathrm{P}-\mathrm{Li}-\mathrm{P}$ system is also obvious from the ${ }^{13} \mathrm{C}\left\{{ }^{1} \mathrm{H}\right\}$ spectra. The ${ }^{13} \mathrm{C}$ nuclei are coupled to both phosphorus atoms over the Li-bridge. Thus the resulting multiplets can be explained. In ${ }^{31} \mathrm{P}$ decoupled spectra the couplings disappear.

Discussions of the crystal structures of $\left[\mathrm{Li}\left\{\mathrm{Me}_{2} \mathrm{P}-\right.\right.$ $\left.\left.\mathrm{CH}_{2} \mathrm{~S}\left(\mathrm{~N}^{t} \mathrm{Bu}\right)_{2}\right\}\right]_{2}$ (1), $\left[\mathrm{Li}\left\{\mathrm{Me}_{2} \mathrm{PCH}_{2} \mathrm{~S}\left(\mathrm{NSiMe}_{3}\right)_{2}\right\}\right]_{2}$ (2), $\left[\mathrm{Li}\left\{\mathrm{Ph}_{2}-\right.\right.$ $\left.\left.\mathrm{PCH}_{2} \mathrm{~S}\left(\mathrm{~N}^{t} \mathrm{Bu}\right)_{2}\right\}\right]_{2}$ (3), $\left[\mathrm{Li}_{2}\left\{\mathrm{Et}_{2} \mathrm{PCH}(\mathrm{Me}) \mathrm{S}\left(\mathrm{NSiMe}_{3}\right)_{2}\right\}\right]_{2}$ (4) and $\left[\mathrm{Li}\left\{\mathrm{Ph}(\mathrm{Me}) \mathrm{PCH}_{2} \mathrm{~S}\left(\mathrm{~N}^{t} \mathrm{Bu}\right)_{2}\right\}\right]_{2}(5)$ reveal that the $\mathrm{N}_{2} \mathrm{SCP}$ ligands are indeed tridentate, containing hard nitrogen and soft phosphorus donor sites. Although the bite of the ligand system is not optimized for lithium cations, the complexes formed are quite stable. Even the softer phosphorus site coordinates the hard lithium cation, yet in solution. It seems that the $\left.\mathrm{R}_{2} \mathrm{PCH}_{2} \mathrm{~S}_{(\mathrm{NR}}\right)_{2}{ }^{-}$ anions are indeed the ligands which are complexing in the desired way. Furthermore, the formation of dimers seems to be favored as it helps to balance the electron deficiency of the metal cations.

The reaction of $\left[\mathrm{Ph}_{2} \mathrm{PCH}_{2} \mathrm{Li} \cdot \mathrm{TMEDA}\right]$ with $\mathrm{S}\left(\mathrm{N}^{t} \mathrm{Bu}\right)_{2}$ yielded diphenylphosphinomethane-sulfurdiimide as lithium-dimer (3) but when the tertiary butyl groups of the imido moiety were replaced by trimethylsilyl groups the compound obtained was [TMEDA. $\left.\mathrm{Li}\left\{\mathrm{Ph}_{2} \mathrm{PCH}_{2} \mathrm{~S}\left(\mathrm{NSiMe}_{3}\right)_{2}\right\}\right]$ (6) (Fig. 9). These results were unexpected as per our strategy and are probably due to the different electronic situation in the $\mathrm{S}\left(\mathrm{NSiMe}_{3}\right)_{2}$ moiety. Compound $\mathbf{6}$ crystallizes from $n$-pentane as a monomer in the monoclinic space group $C 2 / \mathrm{c}$ with half a pentane molecule in the asymmetric unit.

The coordination mode in this compound is new compared to complexes 1-5. The lithium cation is four-fold N-coordinated. The phosphorus atom is not taking part in the coordination as the $\mathrm{Li}$...P distance of $3.23 \AA$ is to long to be regarded a bond..$^{33}$

Nevertheless, an orientation towards the lithium ion can be observed which is due to electrostatic attractions. Furthermore, the S1-C13-P1 angle of $108.79(9)^{\circ}$ indicates the inclination of the phosphorus atom towards the lithium cation. Both phenyl rings are twisted by $90^{\circ}$ with respect to each other, facilitating close packing of the molecules in the crystal. The central $\left(\mathrm{SN}_{2} \mathrm{Li}\right)$ ring is almost perfectly planar with the phosphorus atom residing above this plane. It is aligned with $\mathrm{C} 13, \mathrm{~S} 1, \mathrm{Li1}$ and both nitrogen atoms of the TMEDA molecule. The N1-S1-N2 angle of $103.72(8)^{\circ}$ is slightly more acute than in the lithium complexes $\mathbf{1 - 5}$. The $\mathrm{Li}-\mathrm{N}$ distances range from 2.039(4) $\AA$ (Li1-N2) to 2.167(10) $\AA$ (Li1$\mathrm{N} 3$ ) with the bonds from the TMEDA molecule being marginally

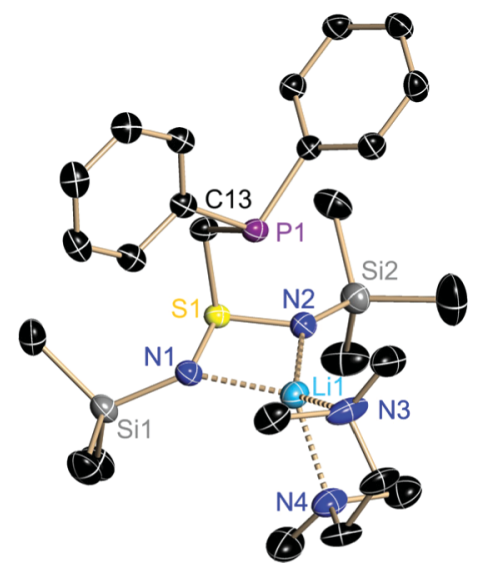

Fig. 9 Molecular structure of [TMEDA. $\left.\mathrm{Li}\left\{\mathrm{Ph}_{2} \mathrm{PCH}_{2}\left(\mathrm{SNSiMe}_{3}\right)_{2}\right\}\right](6)$ in the crystal. Anisotropic displacement parameters are depicted at the $50 \%$ probability level, hydrogen atoms are omitted for clarity. Selected bond lengths $[\AA]$ and angles [ $\left.{ }^{\circ}\right]$ : C13-P1 1.8557(18), C13-S1 1.8338(18), N1-S1 1.6070(15), N2-S1 1.6032(16), N1-Si1 1.7150(16), N2-Si2 1.7114(16); N1-S1-N2 103.72(8), S1-C13-P1 108.79(9), S1-N1-Si1 117.55(9), N1-Li1-N2 75.80(12), N3-Li1-N4 83.7(3).

longer than the bonds from the diimido anion. As the phosphorus side-arm is not donating to the $\mathrm{Li}$ cation it is free for binding to any other soft metal thus providing the opportunity to generate heterobimetallic complexes.

The complexation potential of these Janus head scorpionates is also evident from the facile formation of a stable monomeric complex with magnesium (7) (Scheme 2).

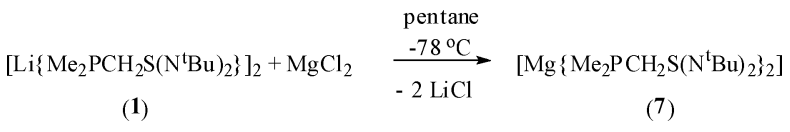

Scheme 2

The reaction of 1 with $\mathrm{MgCl}_{2}$ in a $1: 1$ molar ratio afforded the spirocyclic species $\left[\mathrm{Mg}\left\{\mathrm{Me}_{2} \mathrm{PCH}_{2} \mathrm{~S}\left(\mathrm{~N}^{t} \mathrm{Bu}\right)_{2}\right\}_{2}\right]$ (7). The formation of this magnesium complex demonstrates that the new Janus head ligands are valuable multidentate chelating ligands due to the intramolecular phosphane donor site held in close spacial proximity to the functional imido groups. Complex $\mathbf{7}$ crystallizes from $n$-pentane as colourless plates in the orthorhombic space group Fdd2 (Fig. 10) with half a molecule in the asymmetric unit. As the compound undergoes a phase transition at about $220 \mathrm{~K}$ the X-ray diffraction data set had to be collected at $-23^{\circ} \mathrm{C}$ (see ESI $\dagger$ ).

The monomeric structure shows a distorted octahedral geometry at the central magnesium dication. The molecule has crystallographically imposed two-fold symmetry with the magnesium atom situated on the two-fold axis. The magnesium is bound by two nitrogen atoms and one phosphorus atom of each phosphanyl side-arm as a five-membered chelating ring with bite angles of $74.24(8)^{\circ}$ (N1-Mg1-P1) to $70.82(8)^{\circ}$ (N2-Mg1$\mathrm{P} 1)$. This means that the $\mathrm{N}_{2} \mathrm{SCP}$ ligand behaves in a tridentate manner thus demonstrating tripodal donation by means of two terminal nitrogen atoms and side-arm donation by the phosphorus atom. This side-arm donation brings these ligands into focus as multidentate systems for metal complexation.

Coordination of the magnesium atom shows $\mathrm{Mg}-\mathrm{N}$ distances in the range of 2.102(2) to 2.138(2) $\AA$. These values are 


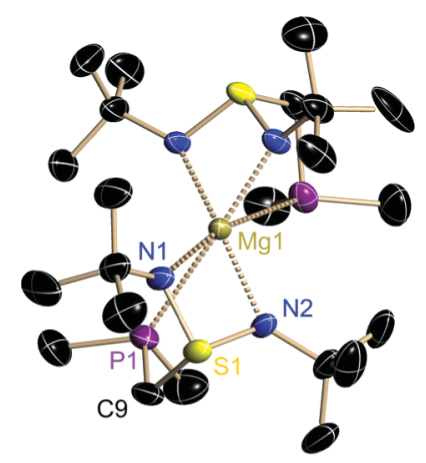

Fig. 10 Molecular structure of $\left[\mathrm{Mg}\left\{\mathrm{Me}_{2} \mathrm{PCH}_{2} \mathrm{~S}\left(\mathrm{~N}^{t} \mathrm{Bu}\right)_{2}\right\}_{2}\right]$ (7) in the crystal. Anisotropic displacement parameters are depicted at the $30 \%$ probability level, hydrogen atoms are omitted for clarity. Selected bond

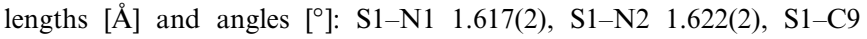
1.838(4), Mg1-N1 2.102(2), Mg1-N2 2.138(2), Mg1-P1 2.9855(13); S1-N1-Mg1 95.69(12), S1-N2-Mg1 94.14(11), N1-Mg1-N2 70.07(9) N1-S1-N2 97.43(12).

similar to those reported for compounds containing a sulfurbonded imido nitrogen donor (2.035-2.295 $\AA$ ). ${ }^{30}$ However, there is a significant difference between the Mg1-N1 (2.102(2) $\AA$ ) and $\mathrm{Mg} 1-\mathrm{N} 2(2.138(2) \AA)$ bonds. The $\mathrm{Mg}-\mathrm{N}$ bond distances are marginally longer than in $\left[\mathrm{Mg}\left\{\left(\mathrm{NSiMe}_{3}\right)_{2} \mathrm{SN}\left(\mathrm{SiMe}_{3}\right)_{2}\right\}_{2}\right]$ (2.0592(6) $\AA)^{25}$ The $\mathrm{Mg}-\mathrm{P}$ bond length is not consistent with the predicted covalent value $(2.65 \AA)$. The distance of 2.9855(13) $\AA$ is enlongated in comparison to $\mathrm{Mg}-\mathrm{P}$ distances in other mononuclear and dinuclear magnesium phosphanides e.g. $\left[\mathrm{BuMg}\left\{\mathrm{P}\left(\mathrm{CH}\left(\mathrm{SiMe}_{3}\right)_{2}\right)\left(\mathrm{C}_{6} \mathrm{H}_{4}-2-\mathrm{OMe}\right)\right\}\right]_{2}(2.5760(8)$ and 2.5978(8) $\AA$ ), $\mathrm{Mg}\left[\mathrm{P}\left\{\mathrm{CH}\left(\mathrm{SiMe}_{3}\right)_{2}\right\}\left\{\mathrm{C}_{6} \mathrm{H}_{4}-2-\mathrm{CH}_{2} \mathrm{NMe}_{2}\right\}\right]_{2}$ (2.556(1) $\AA$ ) and $\left[\mathrm{Mg}\left\{\left[O, O^{\prime}-\left(\mathrm{Me}_{2} \mathrm{PCH}_{2}\right)_{2} \mathrm{C}_{6} \mathrm{H}_{3}\right]_{2}\right\}_{2}\right] 2.761(1)$ and $2.770(1) \AA){ }^{34}$ This elongation of the $\mathrm{Mg}-\mathrm{P}$ bond distance is attributed to the side-arm donation of a phosphanyl rather than coordination of a phosphanide. It suggests a possible application of this ligand in catalytic processes. With a different central metal, it would be feasible to reversibly cleave the metal-phosphorus bond to generate a pendent donor site for substrates or other softer metal cations. The $\mathrm{N}-\mathrm{S}-\mathrm{N}$ bond angle $\left(97.43(12)^{\circ}\right)$ is more acute than in 1 and those in alkali metal derivatives $\left(104.2-110.7^{\circ}\right)$, but spans almost the same range as in comparable compounds with $\mathrm{Mg}^{2+}$ or other dicationic metals $\left(97.6-98.9^{\circ}\right){ }^{25}$ This can be attributed to the higher charge on the magnesium dication, leading to a stronger repulsion between the positively charged sulfur atom and the metal ion.

The magnesium complex $\left[\mathrm{Mg}\left\{\mathrm{Me}_{2} \mathrm{PCH}_{2} \mathrm{~S}\left(\mathrm{NSiMe}_{3}\right)_{2}\right\}_{2}\right]$ (8) was equally isolated by a transmetallation reaction of $\mathbf{2}$ with $\mathrm{MgCl}_{2}$ in an equimolar ratio. Unlike compound 7 , which crystallizes in the orthorhombic space group $F d d 2$ and undergoes a phase transition at about $220 \mathrm{~K}$, this phenomenon could not be observed in 8 . The complex crystallizes from $n$-pentane as colourless blocks in the monoclinic space group $P 2_{1} / \mathrm{n}$ and is monomeric. The phosphanyl diimido moiety is attached to the magnesium atom in the same tripodal fashion involving donation from two terminal nitrogen atoms and the side-arm donation from the phosphorus atom leading to an approximately octahedral coordination polyhedron (Fig. 11). The structural motif is the same as in the magnesium compound 7.

When the reaction of $\left[\mathrm{Ph}_{2} \mathrm{PCH}_{2} \mathrm{Li} \cdot \mathrm{TMEDA}\right]$ and $\mathrm{S}\left(\mathrm{NSiMe}_{3}\right)_{2}$ was carried out in toluene instead of pentane, protona-

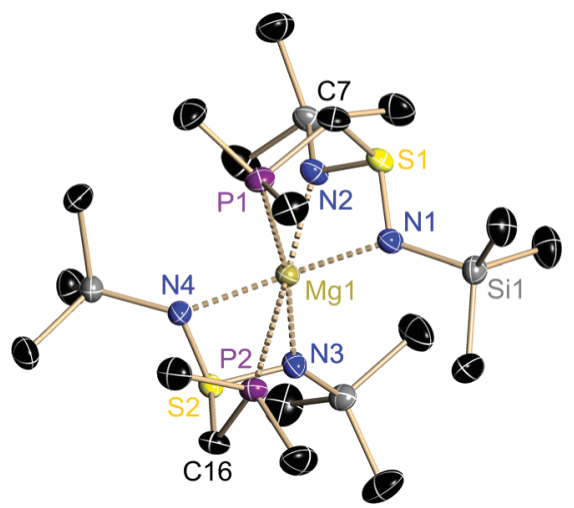

Fig. 11 Molecular structure of $\left[\mathrm{Mg}\left\{\mathrm{Me}_{2} \mathrm{PCH}_{2} \mathrm{~S}\left(\mathrm{NSiMe}_{3}\right)_{2}\right\}_{2}\right](\mathbf{8})$ in the crystal. Anisotropic displacement parameters are depicted at the $50 \%$ probability level, hydrogen atoms are omitted for clarity. Selected bond lengths $[\AA]$ and angles $\left[^{\circ}\right]$ : S1-N1 1.6123(8), S1-N2 1.6111(8), Mg1-N1 2.1481(8), Mg1-N2 2.1276(8), Mg1-P1 2.8570(4); N1-S1-N2 100.44(4), N1-S1-C7 101.86(4), S1-C7-P1 107.75(5), S1-N1-Mg1 92.37(3), S1-N2-Mg1 93.15(4), N1-Mg1-N2 70.81(3), N1-Mg1-P1 72.54(2).

tion of the ligand occurred, resulting in the formation of $\left[\mathrm{Ph}_{2} \mathrm{PCH}_{2}\left(\mathrm{SNSiMe}_{3}\right)\left(\mathrm{HNSiMe}_{3}\right)\right]$ (9). At the moment it is supposed that this happened according to the $\mathrm{C}-\mathrm{H}$ bond activation reaction described in Scheme 3. Thus, a toluene molecule is deprotonated, resulting in the formation of $\mathbf{9}$ and benzyl lithium.

$$
\mathrm{Ph}_{2} \mathrm{PCH}_{2} \mathrm{Li} \cdot \mathrm{TMEDA}+\mathrm{S}\left(\mathrm{NS} \mathrm{iMe}_{3}\right)_{2} \underset{-\mathrm{BzLi}}{\stackrel{\text { toluene }}{\longrightarrow}} \mathrm{Ph}_{2} \mathrm{PCH}_{2} \mathrm{~S}\left(\mathrm{NSiMe}_{3}\right)\left(\mathrm{HNSiMe}_{3}\right)
$$

Scheme 3

Compound 9 crystallizes from toluene layered with $n$-pentane in the monoclinic space group $P 2_{1} / \mathrm{n}$ as a monomer. The solid state structure is shown in Fig. 12.

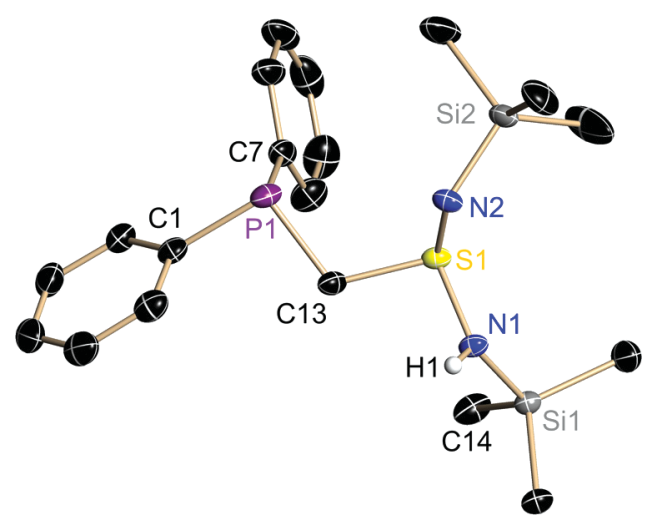

Fig. 12 Molecular structure of $\left[\mathrm{Ph}_{2} \mathrm{PCH}_{2}\left(\mathrm{SNSiMe}_{3}\right)\left(\mathrm{HNSiMe}_{3}\right)\right](9)$ in the crystal. Anisotropic displacement parameters are depicted at the $50 \%$ probability level, hydrogen atoms except $\mathrm{H} 1$, which was freely refined, are omitted for clarity. Selected bond lengths $[\AA]$ and angles $\left[{ }^{\circ}\right]$ : C1-P1 1.8404(13), C13-P1 1.8526(11), C13-S1 1.8092(12), N1-S1 1.6520(9), N2-S1 1.5698(10), N1-Si1 1.7421(10), N2-Si2 1.7184(10); N1-S1-N2 109.26(5), N2-S1-C13 102.99(5), N1-S1-C13 98.36(5), S1-N1-Si1 123.18(6), S1-N2-Si2 122.50(6), C7-P1-C13 102.17(7).

The bond distances for P1-C1 (1.8404(13) A) and P1-C13 (1.8526(11) $\AA$ ) are similar to those of $\mathbf{1 - 5}$. The S1-C13 bond 
distance is also slightly shorter than in complexes 1-5. The N1$\mathrm{S} 1-\mathrm{N} 2\left(109.26(5)^{\circ}\right)$ as well as the S1-C13-P1 angle $\left(113.54(6)^{\circ}\right)$ are widened compared to the lithiated species. The $\mathrm{S}-\mathrm{N}$ bond distances of $1.6520(9)(\mathrm{S} 1-\mathrm{N} 1)$ and 1.5698(10) $\AA$ (S1-N2) are very close to the predicted values for a single and double bond. ${ }^{30}$ They also match the bond lengths of methyl(diimido) sulfinic acid $\mathrm{H}\left(\mathrm{N}^{t} \mathrm{Bu}\right)_{2} \mathrm{SMe}$ and methylene-bis(triimido)sulfonic acid $\mathrm{H}_{2} \mathrm{C}\left\{\mathrm{S}\left(\mathrm{N}^{t} \mathrm{Bu}\right)_{2}\left(\mathrm{NH}^{t} \mathrm{Bu}\right)\right\}_{2}$, which have $\mathrm{S}-\mathrm{N}$ bond distances of 1.52 and $1.68 \AA . .^{31,35}$ Looking at the packing of the molecules in the crystal, it is apparent that $\mathrm{H} 1$ is interacting with the $\pi$-system of the phenyl ring of the next adjacent molecule (C7-C12). Both sixmembered rings are inclined by $99.1^{\circ}$ with respect to each other. This is due to the interaction of $\mathrm{H} 14$ with the $\pi$-system of the second ring ( $\mathrm{C} 1-\mathrm{C} 6)$.

Interestingly, after stirring the reaction mixture for $20 \mathrm{~h}$, there was evidence of a compound which gave a very broad signal at $-39 \mathrm{ppm}$ in the ${ }^{31} \mathrm{P}\left\{{ }^{1} \mathrm{H}\right\}$ NMR spectrum. From this intermediate compound the reaction to the final product $\left(\delta_{31 \mathrm{P}}=-28.8 \mathrm{ppm}\right)$ then proceeded very slowly at $-25^{\circ} \mathrm{C}$. From the NMR spectrum it was concluded that the intermediate compound is some kind of lithium complex. When the same reaction (according to Scheme 3) was carried out in pentane instead of toluene it was possible to crystallize the lithium complex 6 (Fig. 9). The ${ }^{31} \mathrm{P}\left\{{ }^{1} \mathrm{H}\right\}$ NMR spectrum of the crystals shows a very broad signal at $-39 \mathrm{ppm}$. This undoubtedly proves 6 to be the intermediate in the accruement of 9. With the free ligand at hand it should now be much easier to obtain a great variety of mono- and bimetallic complexes directly rather than following the metathesis or salt elimination route. The reaction of 9 with metal amides or metal hydrides will hopefully give new metal complexes. Compound 9 will prove to be an excellent starting material for such reactions as it can be prepared in nearly quantitative yield and great purity.

\section{Conclusion}

With this work we have widened the area of multifunctional ligands and the scope of the Janus head ligands as well. The multifunctionality could easily be achieved just by linking the reactivity of sulfurdiimides and phosphane species. Modification in the ligands is feasible by using different substituents on the phosphane, diimido and C-bridgehead moieties. Compounds 1-5 are dimeric and the main core of the system consists of a $(\mathrm{LiN})_{2}$ ring in which both the lithium atoms are four-coordinated by the

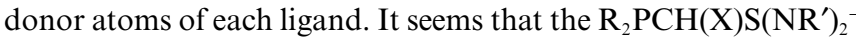
anions are indeed tridentate ligands containing hard nitrogen and soft phosphorus donor sites. The synthesis of complexes 7 and $\mathbf{8}$ provided evidence of the coordination versatility of these newly synthesized ligands. This also indicates that the ligands with podand topology are endowed with intrinsically distinct coordination geometries leading to fascinating bonding and reactivity patterns. Transmetallation of $\mathbf{1 - 5}$ as well as protonation (9) and metal coordination (6) opens a wide synthetic route to introduce a variety of different metals and organometallic residues to the tripodal Janus head ligand. The intrinsic topology of intramolecularly coordinated tridentate ligands may introduce interesting reactivity and electronic properties to the metal complexes. These results are even more significant if we take into account that these were obtained by a simple reaction between the sulfurdiimide and corresponding lithiated phosphane. In addition, the formation of these new ligands also opens up the route to create multimetallic complexes, which is becoming a rather important field nowadays and further developments are anticipated. In essence we succeeded in synthesizing new types of promising Janus head ligands that show interesting hemilabile complexation properties both in the solid state and in solution. Further investigations are under way and open questions are to be addressed to fully understand the stereochemistry of compounds $\mathbf{1 - 5}$ in solution and the protonation of the anions by toluene. This will be achieved e.g. by variable temperature NMR labeling studies.

\section{Experimental}

\section{General}

All manipulations were performed either in an inert gas atmosphere of purified dry nitrogen or argon with standard Schlenk techniques or in an argon glove box. The glassware was dried at $130^{\circ} \mathrm{C}$, assembled hot and cooled under vacuum. All solvents were dried over appropriate alkali metals, distilled and degassed prior to use. The reactants were synthesized according to the literature reports: $\mathrm{S}\left(\mathrm{NSiMe}_{3}\right)_{2},{ }^{36}\left(\mathrm{~S}\left(\mathrm{~N}^{\prime} \mathrm{Bu}\right)_{2}\right)^{37}$ and $\left[\mathrm{Ph}_{2} \mathrm{PCH}_{2} \mathrm{Li} \cdot \mathrm{TMEDA}\right] \cdot{ }^{38}$ ${ }^{t} \mathrm{BuLi}$ and ${ }^{n} \mathrm{BuLi}$ were supplied by Chemetall GmbH. All NMR spectra were either recorded on a Bruker Avance DPX $300 \mathrm{MHz}$ or Bruker Avance DRX $500 \mathrm{MHz}$ spectrometer using TMS $\left({ }^{1} \mathrm{H}\right.$, ${ }^{13} \mathrm{C}$ and $\left.{ }^{29} \mathrm{Si}\right), \mathrm{H}_{3} \mathrm{PO}_{4}\left(85^{\circ}\right)\left({ }^{31} \mathrm{P}\right)$ and $\mathrm{LiCl}\left({ }^{7} \mathrm{Li}\right)$ as the external reference and the protons of the deuterated solvents as the internal standard. Elemental analyses $(\mathrm{C}, \mathrm{H}, \mathrm{N}$ and $\mathrm{S})$ were carried out at the Mikroanalytisches Labor, Institut für Anorganische Chemie, Universität Göttingen.

\section{General preparation of lithiated phosphanes}

${ }^{t} \mathrm{BuLi}(1.38 \mathrm{M})$ was reduced to half of its volume and the corresponding phosphane $\left(\mathrm{PMe}_{3}, \mathrm{PEt}_{3}, \mathrm{Me}_{2} \mathrm{PPh}\right)$ was added very slowly at room temperature. After stirring for $14 \mathrm{~h}$ and refluxing for $2 \mathrm{~h}$ in the case of $\mathrm{PEt}_{3}$, the white to light yellow precipitates were filtered, washed with $n$-pentane $(3 \times 5 \mathrm{~mL})$ and dried in vacuo.

$\left[\mathbf{L i}\left\{\mathbf{M e}_{2} \mathbf{P C H} \mathbf{C H}_{2} \mathbf{S}\left(\mathbf{N}^{t} \mathbf{B u}\right)_{2}\right\}\right]_{2}$ (1). $1.67 \mathrm{~g}(9.60 \mathrm{mmol}, 2.0$ eq.) $\mathrm{S}\left(\mathrm{N}^{t} \mathrm{Bu}\right)_{2}$ were slowly added to a slurry of $0.79 \mathrm{~g}(9.60 \mathrm{mmol}$, 2.0 eq.) $\mathrm{Me}_{2} \mathrm{PCH}_{2} \mathrm{Li}$ in $60 \mathrm{~mL} n$-pentane at $-78^{\circ} \mathrm{C}$. The mixture was yellow at first and became light orange after stirring overnight at room temperature. The clear solution was reduced to half of its volume in vacuo. Storage at $-25{ }^{\circ} \mathrm{C}$ for 5 days yielded colorless crystals. Yield: $1.65 \mathrm{~g}(3.20 \mathrm{mmol}) 67 \%$; mp $143{ }^{\circ} \mathrm{C}$ (from pentane, decomposition); Found: C, 51.6; H, 10.9; N, 10.8; $\mathrm{S}, 12.3 . \mathrm{C}_{22} \mathrm{H}_{52} \mathrm{~N}_{4} \mathrm{P}_{2} \mathrm{~S}_{2} \mathrm{Li}_{2}$ requires $\mathrm{C}, 51.6 ; \mathrm{H}, 10.2 ; \mathrm{N}, 10.9 ; \mathrm{S}$ $12.5 \% ; \delta^{1} \mathrm{H}\left(500.13 \mathrm{MHz} ; \mathrm{C}_{6} \mathrm{D}_{6}\right): 0.896\left(6 \mathrm{H}, \mathrm{d},{ }^{2} J_{\mathrm{P}-\mathrm{H}}=0.55 \mathrm{~Hz}\right.$, $\left.\mathrm{P}\left(\mathrm{CH}_{3}\right)_{2}\right), 0.898\left(6 \mathrm{H}, \mathrm{d},{ }^{2} J_{\mathrm{P}-\mathrm{H}}=0.55 \mathrm{~Hz}, \mathrm{P}\left(\mathrm{CH}_{3}\right)_{2}\right), 1.44(36 \mathrm{H}, \mathrm{s}$, $\left.\mathrm{C}\left(\mathrm{CH}_{3}\right)_{3}\right), 2.676\left(2 \mathrm{H}, \mathrm{d},{ }^{2} J_{\mathrm{P}-\mathrm{H}}=0.92 \mathrm{~Hz}, \mathrm{PCH}_{2} \mathrm{~S}\right), 2.678(2 \mathrm{H}$, $\left.\mathrm{d},{ }^{2} J_{\mathrm{P}-\mathrm{H}}=0.92 \mathrm{~Hz}, \mathrm{PCH}_{2} \mathrm{~S}\right) ; \delta{ }^{13} \mathrm{C}\left(125.76 \mathrm{MHz} ; \mathrm{C}_{6} \mathrm{D}_{6}\right): 13.70(\mathrm{~d}$, $\left.{ }^{1} J_{\mathrm{P}-\mathrm{C}}=1.65 \mathrm{~Hz}, \mathrm{PCH}_{3}\right), 13.73\left(\mathrm{~d},{ }^{1} J_{\mathrm{P}-\mathrm{C}}=1.65 \mathrm{~Hz}, \mathrm{PCH}_{3}\right), 33.76(\mathrm{~s}$, $\left.\mathrm{C}\left(\mathrm{CH}_{3}\right)_{3}\right), 54.02\left(\mathrm{~s}, \mathrm{C}\left(\mathrm{CH}_{3}\right)_{3}\right), 64.83\left(\mathrm{~d},{ }^{1} J_{\mathrm{P}-\mathrm{C}}=2.99 \mathrm{~Hz}, \mathrm{PCH}_{2} \mathrm{~S}\right)$, $64.92\left(\mathrm{~d},{ }^{1} J_{\mathrm{PC}}=2.99 \mathrm{~Hz}, \mathrm{PCH}_{2} \mathrm{~S}\right) ; \delta{ }^{31} \mathrm{P}\left(202.46 \mathrm{MHz} ; \mathrm{C}_{6} \mathrm{D}_{6}\right)$ : -67.0 (sept, $\left.{ }^{1} J_{\text {P Li }}=18.5 \mathrm{~Hz}, \mathrm{Li} P \mathrm{Li}\right) ;{ }^{7}{ }_{\mathrm{Li}}\left(194.37 \mathrm{MHz} ; \mathrm{C}_{6} \mathrm{D}_{6}\right)$ : $2.22 \mathrm{ppm}\left(\mathrm{t},{ }^{1} J_{\mathrm{P}-\mathrm{Li}}=18.5 \mathrm{~Hz}, \mathrm{P} L i \mathrm{P}\right)$.

$\left[\mathrm{Li}\left\{\mathrm{Me}_{2} \mathbf{P C H}_{2} \mathbf{S}\left(\mathrm{NSiMe}_{3}\right)_{2}\right\}\right]_{2} \quad$ (2). To a suspension of $\mathrm{Me}_{2} \mathrm{PCH}_{2} \mathrm{Li}(0.60 \mathrm{~g}, 7.32 \mathrm{mmol}, 2.0 \mathrm{eq})$ in $n$-pentane $(40 \mathrm{~mL})$ $\mathrm{S}\left(\mathrm{NSiMe}_{3}\right)_{2}(1.51 \mathrm{~g}, 7.32 \mathrm{mmol}, 2.0 \mathrm{eq})$ was added very slowly 
at $-78{ }^{\circ} \mathrm{C}$. The suspension was allowed to warm to room temperature after $20 \mathrm{~min}$ and stirred for $24 \mathrm{~h}$. The green-yellow solution was filtered, reduced to half of its volume and stored at $-25{ }^{\circ} \mathrm{C}$. Colourless crystals, suitable for structural analysis were obtained after two days. Yield: $1.64 \mathrm{~g}, 2.85 \mathrm{mmol}, 78 \%$; $\mathrm{mp} 147.3{ }^{\circ} \mathrm{C}$ (from pentane, decomp.); Found C, 37.21; H, 9.00; $\mathrm{N}, 9.92 ; \mathrm{S}, 11.14 . \mathrm{C}_{18} \mathrm{H}_{52} \mathrm{~N}_{4} \mathrm{Si}_{4} \mathrm{P}_{2} \mathrm{~S}_{2} \mathrm{Li}_{2}$ requires C, 37.21; H, 9.08; $\mathrm{N}, 9.71 ; \mathrm{S}, 11.12 \% ; \delta{ }^{1} \mathrm{H}\left(500.13 \mathrm{MHz}, \mathrm{C}_{6} \mathrm{D}_{6}\right): 0.32(36 \mathrm{H}, \mathrm{s}$, $\left.\mathrm{Si}\left(\mathrm{CH}_{3}\right)_{3}\right), 0.83\left(12 \mathrm{H}, \mathrm{s}, \mathrm{P}\left(\mathrm{CH}_{3}\right)_{2}\right), 2.65\left(4 \mathrm{H}, \mathrm{s}, \mathrm{PCH}_{2} \mathrm{~S}\right) ; \delta{ }^{13} \mathrm{C}$ $\left(125.77 \mathrm{MHz}, \mathrm{C}_{6} \mathrm{D}_{6}\right): 2.92\left(\mathrm{Si}\left(\mathrm{CH}_{3}\right)_{3}\right), 12.92\left(\mathrm{~d}, \mathrm{P}\left(\mathrm{CH}_{3}\right)_{2},{ }^{1} \mathrm{~J}_{\mathrm{P}-\mathrm{C}}=\right.$ $3.31 \mathrm{~Hz}), 66.51\left(\mathrm{~d}, \mathrm{PCH}_{2} \mathrm{~S},{ }^{1} J_{\mathrm{P}-\mathrm{C}}=10.94 \mathrm{~Hz}\right) ; \delta^{31}{ }_{\mathrm{P}}(202.46 \mathrm{MHz}$, $\mathrm{C}_{6} \mathrm{D}_{6}$ ): -67.87 (hept, ${ }^{1} J_{\mathrm{P}-\mathrm{Li}}=20.84 \mathrm{~Hz}$ ); $\delta^{7} \mathrm{Li}\left(194.37 \mathrm{~Hz}, \mathrm{C}_{6} \mathrm{D}_{6}\right)$ : $2.19\left(\mathrm{t},{ }^{1} J_{\mathrm{P}-\mathrm{Li}}=20.84 \mathrm{~Hz}\right) ;{ }^{29} \mathrm{Si}\left(99.36 \mathrm{MHz}, \mathrm{C}_{6} \mathrm{D}_{6}\right):-2.71(\mathrm{~s}$, $\left.{ }^{1} J_{\mathrm{N}-\mathrm{Si}}=27.55 \mathrm{~Hz}\right)$.

$\left[\mathbf{L i}\left\{\mathbf{P h}_{2} \mathbf{P C H}_{2} \mathbf{S}\left(\mathbf{N}^{t} \mathbf{B u}\right)_{2}\right\}\right]_{2} \quad$ (3). $1.74 \mathrm{~g}$ (10.0 mmol, 2.0 eq.) $\mathrm{S}\left(\mathrm{N}^{\prime} \mathrm{Bu}\right)_{2}$ were slowly added to a slurry of $2.06 \mathrm{~g}(10.0 \mathrm{mmol}$, 2.0 eq. $)\left[\mathrm{Li}\left(\mathrm{H}_{2} \mathrm{CPPh}_{2}\right) \cdot \mathrm{TMEDA}\right]$ in $60 \mathrm{~mL} n$-pentane at $-78^{\circ} \mathrm{C}$. After stirring overnight at room temperature, the white precipitate was filtered, washed with pentane and dissolved in toluene. The light yellow solution was kept at $-25^{\circ} \mathrm{C}$ for three days, yielding colourless crystals. Yield: $2.05 \mathrm{~g}(2.88 \mathrm{mmol}) 78 \%$; mp $123{ }^{\circ} \mathrm{C}$ (from toluene, decomp.); Found: C, 64.6; H, 7.7; N, 6.5; S, 8.1. $\mathrm{C}_{42} \mathrm{H}_{60} \mathrm{~N}_{4} \mathrm{P}_{2} \mathrm{~S}_{2} \mathrm{Li}_{2}$ requires $\mathrm{C}$, 66.3; $\mathrm{H}, 8.0 ; \mathrm{N}, 7.4 ; \mathrm{S}, 8.4 \% ; \delta{ }^{1} \mathrm{H}$ $\left(500.13 \mathrm{MHz} ; \mathrm{C}_{6} \mathrm{D}_{6}\right): 1.37\left(36 \mathrm{H}, \mathrm{s}, \mathrm{C}\left(\mathrm{CH}_{3}\right)_{3}\right), 3.64\left(4 \mathrm{H}, \mathrm{s}, \mathrm{PCH}_{2} \mathrm{~S}\right)$, 6.98-7.01 (4 H, m, $p-\mathrm{H}), 7.04-7.07(8 \mathrm{H}, \mathrm{m}, m-\mathrm{H}), 7.56-7.59(8$ $\mathrm{H}, \mathrm{m}, o-\mathrm{H}) ; \delta{ }^{13} \mathrm{C}\left(125.76 \mathrm{MHz} ; \mathrm{C}_{6} \mathrm{D}_{6}\right): 33.60\left(\mathrm{~s}, \mathrm{C}\left(\mathrm{CH}_{3}\right)_{3}\right), 54.31$ (s, $\left.C\left(\mathrm{CH}_{3}\right)_{3}\right), 62.26\left(\mathrm{~d},{ }^{1} J_{\mathrm{P}-\mathrm{C}}=17.49 \mathrm{~Hz}, \mathrm{PCH}_{2} \mathrm{~S}\right), 128.63-128.76$ $(\mathrm{m}, i-\mathrm{C}), 128.92(\mathrm{~s}, p-\mathrm{C}), 133.45-133.63\left(\mathrm{~m},{ }^{2} J_{\mathrm{P}-\mathrm{C}}=18.30 \mathrm{~Hz}, o-\right.$ C), $137.79-137.82\left(\mathrm{~m},{ }^{3} J_{\mathrm{P}-\mathrm{C}}=3.76 \mathrm{~Hz}, m-\mathrm{C}\right) ; \delta^{31} \mathrm{P}(202.46 \mathrm{MHz}$; $\left.\mathrm{C}_{6} \mathrm{D}_{6}\right):-32.57$ (br s, LiPLi); $\delta^{7} \mathrm{Li}\left(194.37 \mathrm{MHz} ; \mathrm{C}_{6} \mathrm{D}_{6}\right): 2.63 \mathrm{ppm}$ $\left(\mathrm{t},{ }^{1} J_{\mathrm{P}-\mathrm{Li}}=12.8 \mathrm{~Hz}, \mathrm{P} L i \mathrm{P}\right)$.

$\left[\mathbf{L i}\left\{\mathbf{E t}_{2} \mathbf{P C H}(\mathbf{M e}) \mathbf{S}\left(\mathrm{NSiMe}_{3}\right)_{2}\right\}\right]_{2}$ (4). To a suspension of $\mathrm{Et}_{2} \mathrm{PCH}(\mathrm{Me}) \mathrm{Li}(0.13 \mathrm{~g}, 0.81 \mathrm{mmol}, 2.0$ eq. $)$ in $n$-pentane $(10 \mathrm{~mL})$ $\mathrm{S}\left(\mathrm{NSiMe}_{3}\right)_{2}(0.17 \mathrm{~g}, 0.81 \mathrm{mmol}, 2.0$ eq. $)$ was added very slowly at $-78{ }^{\circ} \mathrm{C}$. After $20 \mathrm{~min}$ the suspension was allowed to warm to room temperature and stirred for $24 \mathrm{~h}$. The yellow solution was reduced to $1 / 2$ of its volume and stored at $-25^{\circ} \mathrm{C}$. After one week, colourless crystals, suitable for structural analysis, were obtained. Yield: $0.21 \mathrm{~g}, 0.32 \mathrm{mmol}, 80 \%$; mp $138.9^{\circ} \mathrm{C}$ (from pentane, decomp.); Found: C, 42.96; H, 9.58; N, 8.70; S, 9.83. $\mathrm{C}_{24} \mathrm{H}_{64} \mathrm{~N}_{4} \mathrm{Si}_{4} \mathrm{P}_{2} \mathrm{~S}_{2} \mathrm{Li}_{2}$ requires $\mathrm{C}, 43.60 ; \mathrm{H}, 9.76 ; \mathrm{N}, 8.47 ; \mathrm{S}, 9.70 \% ; \delta$ ${ }^{1} \mathrm{H}\left(500.13 \mathrm{MHz}, \mathrm{C}_{6} \mathrm{D}_{6}\right): 0.36-0.37\left(72 \mathrm{H}, \mathrm{m}, 2 \times \mathrm{Si}\left(\mathrm{CH}_{3}\right)_{3}\right), 0.92-$ $1.02\left(24 \mathrm{H}, \mathrm{m}, 2 \times \mathrm{PCH}_{2} \mathrm{CH}_{3}\right), 1.17-1.22\left(24 \mathrm{H}, \mathrm{m}, 2 \times \mathrm{PCH}_{2} \mathrm{CH}_{3}\right.$, $\left.1 / 3 \times \mathrm{PCH}\left(\mathrm{CH}_{3}\right) \mathrm{S}\right), 1.43-1.54\left(4 \mathrm{H}, \mathrm{m}, 2 / 3 \times \mathrm{PCH}\left(\mathrm{CH}_{3}\right) \mathrm{S}\right), 2.59$ $2.68\left(4 \mathrm{H}, \mathrm{m}, 2 \times \mathrm{PCH}\left(\mathrm{CH}_{3}\right) \mathrm{S}\right) ;{ }^{13} \mathrm{C}\left(125.77 \mathrm{MHz}, \mathrm{C}_{6} \mathrm{D}_{6}\right): 3.09$ $3.42\left(\mathrm{~m}, \mathrm{Si}\left(\mathrm{CH}_{3}\right)_{3}, 10.46-11.21\left(\mathrm{~m}, \mathrm{PCH}_{2} \mathrm{CH}_{3}, \mathrm{PCH}_{2} \mathrm{CH}_{3}\right), 14.10\right.$ $\left(\mathrm{dd},{ }^{2} J_{\mathrm{P}-\mathrm{C}}=111.5 \mathrm{~Hz},{ }^{4} J_{\mathrm{P}-\mathrm{C}}=8.81 \mathrm{~Hz}, \operatorname{PCH}\left(\mathrm{CH}_{3}\right) \mathrm{S}\right), 17.24(\mathrm{dd}$, $\left.{ }^{2} J_{\mathrm{P}-\mathrm{C}}=72.57 \mathrm{~Hz},{ }^{4} J_{\mathrm{P}-\mathrm{C}}=6.60 \mathrm{~Hz}, \mathrm{PCH}\left(\mathrm{CH}_{3}\right) \mathrm{S}\right), 63.34\left(\mathrm{~d},{ }^{1} J_{\mathrm{P}-\mathrm{C}}=\right.$ $\left.13.48 \mathrm{~Hz}, \mathrm{PCH}\left(\mathrm{CH}_{3}\right) \mathrm{S}\right), 64.87\left(\mathrm{~d},{ }^{1} J_{\mathrm{P}-\mathrm{C}}=14.34 \mathrm{~Hz}, \mathrm{PCH}\left(\mathrm{CH}_{3}\right) \mathrm{S}\right)$; $\delta^{31} \mathrm{P}\left(202.46 \mathrm{MHz}, \mathrm{C}_{6} \mathrm{D}_{6}\right):-30.74$ (hept, $\left.{ }^{1} J_{\mathrm{P}-\mathrm{Li}}=18.81 \mathrm{~Hz}, \mathrm{Li} P \mathrm{Li}\right)$, -27.34 (hept, $\left.{ }^{1} J_{\mathrm{P}-\mathrm{Li}}=19.16 \mathrm{~Hz}, \mathrm{Li} P \mathrm{Li}\right) ; \delta^{7}{ }_{\mathrm{Li}}\left(194.37 \mathrm{~Hz}, \mathrm{C}_{6} \mathrm{D}_{6}\right)$ : $2.27\left(\mathrm{t},{ }^{1} J_{\mathrm{P}-\mathrm{Li}}=18.81 \mathrm{~Hz}, \mathrm{P} L i \mathrm{P}\right), 2.37\left(\mathrm{t},{ }^{1} J_{\mathrm{P}-\mathrm{Li}}=19.16 \mathrm{~Hz}, \mathrm{P} L i \mathrm{P}\right)$; $\delta^{29} \mathrm{Si}\left(99.36 \mathrm{MHz}, \mathrm{C}_{6} \mathrm{D}_{6}\right):-4.19\left(\mathrm{~s},{ }^{1} J_{\mathrm{N}-\mathrm{Si}}=26.61 \mathrm{~Hz}, \mathrm{~N} S i\left(\mathrm{CH}_{3}\right)_{3}\right)$, $-3.65\left(\mathrm{~s},{ }^{1} J_{\mathrm{N}-\mathrm{Si}}=27.16 \mathrm{~Hz}, \mathrm{~N} S i\left(\mathrm{CH}_{3}\right)_{3}\right),-1.05\left(\mathrm{~s},{ }^{1} J_{\mathrm{N}-\mathrm{Si}}=27.61 \mathrm{~Hz}\right.$, $\left.\mathrm{N} S i\left(\mathrm{CH}_{3}\right)_{3}\right),-0.55\left(\mathrm{~s},{ }^{1} J_{\mathrm{N}-\mathrm{Si}}=27.61 \mathrm{~Hz}, \mathrm{~N} S i\left(\mathrm{CH}_{3}\right)_{3}\right)$.

$\left[\mathbf{L i}\left\{\mathbf{M e}(\mathbf{P h}) \mathbf{P C H}_{2} \mathbf{S}\left(\mathbf{N}^{t} \mathbf{B u}\right)_{2}\right\}\right]_{2} \quad$ (5). To a suspension of $\mathrm{Me}(\mathrm{Ph}) \mathrm{PCH}_{2} \mathrm{Li}(1.50 \mathrm{~g}, 11.4 \mathrm{mmol}, 2.0$ eq.) in $n$-pentane $(30 \mathrm{~mL})$
$\mathrm{S}\left(\mathrm{N}^{t} \mathrm{Bu}\right)_{2}(1.98 \mathrm{~g}, 11.4 \mathrm{mmol}, 2.0$ eq.) was added very slowly at $-78^{\circ} \mathrm{C}$. After $20 \mathrm{~min}$ the suspension was allowed to warm to room temperature and stirred for $24 \mathrm{~h}$. The yellow-orange solution was reduced to $2 / 3$ of its volume and stored at $-25{ }^{\circ} \mathrm{C}$. After three days, colourless crystals suitable for structural analysis, were obtained. Yield: $2.65 \mathrm{~g}, 4.16 \mathrm{mmol}, 73 \%$; $\mathrm{mp} 125.5^{\circ} \mathrm{C}$ (from pentane, decomp.); Found: C, 59.33; H, 8.75; N, 8.79; S, 10.26 . $\mathrm{C}_{32} \mathrm{H}_{56} \mathrm{~N}_{4} \mathrm{P}_{2} \mathrm{~S}_{2} \mathrm{Li}_{2}$ requires C, 60.36; H, 8.86; N, 8.80; $\mathrm{S}, 10.07 \%$; $\delta{ }^{1} \mathrm{H}\left(500.13 \mathrm{MHz}, \mathrm{C}_{6} \mathrm{D}_{6}\right): 1.20\left(3 \mathrm{H}, \mathrm{s}, \mathrm{PCH}_{3}\right), 1.32(3 \mathrm{H}, \mathrm{s}$, $\left.\mathrm{PCH}_{3}\right), 1.37\left(9 \mathrm{H}, \mathrm{s}, \mathrm{C}\left(\mathrm{CH}_{3}\right)_{3}\right), 1.38\left(9 \mathrm{H}, \mathrm{s}, \mathrm{C}\left(\mathrm{CH}_{3}\right)_{3}\right), 1.43(9 \mathrm{H}, \mathrm{s}$, $\left.\mathrm{C}\left(\mathrm{CH}_{3}\right)_{3}\right), 1.45\left(9 \mathrm{H}, \mathrm{s}, \mathrm{C}\left(\mathrm{CH}_{3}\right)_{3}\right), 2.96-3.12\left(4 \mathrm{H}, \mathrm{m}, \mathrm{PCH}_{2} \mathrm{~S}\right)$, 7.02-7.05 (2 H, m, $p-\mathrm{H}), 7.08-7.12(4 \mathrm{H}, \mathrm{m}, m-\mathrm{H}), 7.47-7.51(4$ $\mathrm{H}, \mathrm{m}, o-\mathrm{H}) ; \delta^{13} \mathrm{C}\left(125.76 \mathrm{MHz}, \mathrm{C}_{6} \mathrm{D}_{6}\right): 13.43\left(\mathrm{dd},{ }^{1} J_{\mathrm{P}-\mathrm{C}}=4.73 \mathrm{~Hz}\right.$, $\left.{ }^{3} J_{\mathrm{P}-\mathrm{C}}=3.01 \mathrm{~Hz}, \mathrm{PLiPCH} \mathrm{H}_{3}\right), 13.60\left(\mathrm{dd},{ }^{1} J_{\mathrm{P}-\mathrm{C}}=5.02 \mathrm{~Hz},{ }^{3} J_{\mathrm{P}-\mathrm{C}}=\right.$ $\left.2.44 \mathrm{~Hz}, \mathrm{PLiPCH} \mathrm{H}_{3}\right), 33.51-33.67\left(\mathrm{~m}, \mathrm{C}\left(\mathrm{CH}_{3}\right)_{3}\right), 53.94-54.40(\mathrm{~m}$, $\left.C\left(\mathrm{CH}_{3}\right)_{3}\right), 64.10-64.27\left(\mathrm{~m}, \mathrm{PC} \mathrm{H}_{2} \mathrm{~S}\right), 128.56-128.70(\mathrm{~m}, o-\mathrm{C})$, $131.89-132.27(\mathrm{~m}, p-\mathrm{C}), 139.65\left(\mathrm{dd},{ }^{3} J_{\mathrm{P}-\mathrm{C}}=3.49 \mathrm{~Hz},{ }^{5} J_{\mathrm{P}-\mathrm{C}}=\right.$ $1.99 \mathrm{~Hz}, m-\mathrm{C}), 139.97\left(\mathrm{dd},{ }^{1} J_{\mathrm{P}-\mathrm{C}}=3.16 \mathrm{~Hz},{ }^{3} J_{\mathrm{P}-\mathrm{C}}=2.24 \mathrm{~Hz}, i-\mathrm{C}\right)$; $\delta{ }^{31} \mathrm{P}=\left(202.46 \mathrm{MHz}, \mathrm{C}_{6} \mathrm{D}_{6}\right):-(51.98-51.51)(\mathrm{m}, \mathrm{Li} P \mathrm{Li}) ; \delta^{7} \mathrm{Li}$ $\left(194.37 \mathrm{~Hz}, \mathrm{C}_{6} \mathrm{D}_{6}\right): 2.41\left(\mathrm{t},{ }^{1} J_{\mathrm{P}-\mathrm{Li}}=13.43 \mathrm{~Hz}, \mathrm{P} L i \mathrm{P}\right)$.

[TMEDA. $\mathbf{L i}\left\{\mathbf{P h}_{2} \mathbf{P C H} \mathbf{S}\left(\mathrm{NSiMe}_{3}\right)_{2}\right\}$ ] (6). To a slurry of $\mathrm{Ph}_{2} \mathrm{PCH}_{2} \mathrm{Li}$-TMEDA (3.01 g, $9.30 \mathrm{mmol}, 1.0$ eq.) in $n$-pentane $(50 \mathrm{~mL}) \mathrm{S}\left(\mathrm{NSiMe}_{3}\right)_{2}(1.92 \mathrm{~g}, 9.30 \mathrm{mmol}, 1.0$ eq.) was slowly added at $-78{ }^{\circ} \mathrm{C}$. After stirring at room temperature overnight, the solution was filtered over celite, reduced in volume and stored at $-25^{\circ} \mathrm{C}$, yielding colourless crystals after 2 days.

Yield: $4.44 \mathrm{~g}, 8.40 \mathrm{mmol}, 90 \%$; Found: C, 56.08; H, 8.48; N, 10.37; S, 6.28. $\mathrm{C}_{25} \mathrm{H}_{46} \mathrm{~N}_{4} \mathrm{Si}_{2} \mathrm{PSLi}$ requires C, 56.78; H, 8.77; N, $10.59 ; \mathrm{S}, 6.06 \% ; \delta^{1} \mathrm{H}\left(300.13 \mathrm{MHz}, \mathrm{C}_{6} \mathrm{D}_{6}\right): 0.28\left(18 \mathrm{H}, \mathrm{s}, \mathrm{Si}\left(\mathrm{CH}_{3}\right)_{3}\right)$, $1.77\left(4 \mathrm{H}, \mathrm{s}\right.$ br, $\left.\mathrm{N}\left(\mathrm{CH}_{2}\right)_{2} \mathrm{~N}\right), 2.07\left(12 \mathrm{H}, \mathrm{s},\left(\mathrm{CH}_{3}\right)_{2} \mathrm{~N}\right), 3.47(2 \mathrm{H}, \mathrm{s}$ br, $\left.\mathrm{SCH}_{2} \mathrm{P}\right), 6.99-7.12(6 \mathrm{H}, \mathrm{m}, o-\mathrm{H}, p-\mathrm{H}), 7.59-7.70(4 \mathrm{H}, \mathrm{m}, m-$ $\mathrm{H}) ; \delta^{13} \mathrm{C}\left(125.76 \mathrm{MHz}, \mathrm{C}_{6} \mathrm{D}_{6}\right): 3.19\left(\mathrm{Si}\left(\mathrm{CH}_{3}\right)_{3}\right), 45.82\left(\left(\mathrm{CH}_{3}\right)_{2} \mathrm{~N}\right)$, $56.66\left(\mathrm{~N}\left(\mathrm{CH}_{2}\right)_{2}\right), 70.84\left(\mathrm{~d},{ }^{1} J_{\mathrm{P}-\mathrm{C}}=23.99 \mathrm{~Hz}, \mathrm{PCH}_{2} \mathrm{~S}\right), 128.46(\mathrm{~d}$, $\left.{ }^{3} J_{\mathrm{P}-\mathrm{C}}=6.02 \mathrm{~Hz}, m-\mathrm{C}\right), 132.48\left(\mathrm{~d},{ }^{4} J_{\mathrm{P}-\mathrm{C}}=18.74 \mathrm{~Hz}, p-\mathrm{C}\right), 133.90(\mathrm{~d}$, $\left.{ }^{2} J_{\mathrm{P}-\mathrm{C}}=19.50 \mathrm{~Hz}, o-\mathrm{C}\right), 142.04\left(\mathrm{~d},{ }^{1} J_{\mathrm{P}-\mathrm{C}}=14.98 \mathrm{~Hz}\right.$, ipso-C $) ; \delta^{31} \mathrm{P}$ $\left(121.49 \mathrm{MHz}, \mathrm{C}_{6} \mathrm{D}_{6}\right):-38.78\left(\mathrm{~s} \mathrm{br}, P \mathrm{CH}_{2} \mathrm{~S}\right) ; \delta^{7} \mathrm{Li}(194.37 \mathrm{MHz}$, $\left.\mathrm{C}_{6} \mathrm{D}_{6}\right): 1.00(\mathrm{~s}) ; \delta^{29} \mathrm{Si}\left(99.36 \mathrm{MHz}, \mathrm{C}_{6} \mathrm{D}_{6}\right):-8.29(\mathrm{~s})$.

$\left[\mathbf{M g}\left\{\mathbf{M e}_{2} \mathbf{P C H} \mathbf{H}_{2} \mathbf{S}\left(\mathbf{N}^{t} \mathbf{B u}\right)_{2}\right\}_{2}\right]$ (7). $0.50 \mathrm{~g}(0.98 \mathrm{mmol}, 1.0$ eq.) 1 and $0.90 \mathrm{~g}\left(0.98 \mathrm{mmol}, 1.0\right.$ eq.) $\mathrm{MgCl}_{2}$ were combined in an argon drybox and dissolved in $40 \mathrm{~mL} n$-pentane/thf at room temperature. After stirring overnight, the solvent was removed in vacuo and the resulting yellow powder suspended in $20 \mathrm{~mL} n$ pentane. The suspension was filtered over celite and the volume of the filtrate was reduced. Colourless crystals were obtained after storing the yellow solution for 3 days at $4{ }^{\circ} \mathrm{C}$. Yield: $0.33 \mathrm{~g}$ (0.63 mmol) $64 \%$; mp $165.5^{\circ} \mathrm{C}$ (from pentane, decomp.); Found: C, 49.9; H, 10.0; N, 11.0; S, 12.2. $\mathrm{C}_{22} \mathrm{H}_{52} \mathrm{~N}_{4} \mathrm{P}_{2} \mathrm{~S}_{2} \mathrm{Mg}$ requires $\mathrm{C}$, $50.5 ; \mathrm{H}, 10.0 ; \mathrm{N}, 10.7 ; \mathrm{S}, 12.3 ; \delta^{1} \mathrm{H}\left(500.13 \mathrm{MHz} ; \mathrm{C}_{6} \mathrm{D}_{6}\right): 0.98(12$ $\left.\mathrm{H}, \mathrm{t},{ }^{2} J_{\mathrm{P}-\mathrm{H}}=1.15 \mathrm{~Hz}, \mathrm{P}\left(\mathrm{CH}_{3}\right)_{2}\right), 1.39\left(36 \mathrm{H}, \mathrm{s}, \mathrm{C}\left(\mathrm{CH}_{3}\right)_{3}\right), 2.21(4$ $\left.\mathrm{H}, \mathrm{t},{ }^{2} J_{\mathrm{P}-\mathrm{H}}=1.65 \mathrm{~Hz}, \mathrm{PC} H_{2} \mathrm{~S}\right) ; \delta^{13} \mathrm{C}\left(125.76 \mathrm{MHz} ; \mathrm{C}_{6} \mathrm{D}_{6}\right): 14.67$ $\left(\mathrm{d},{ }^{1} J_{\mathrm{P}-\mathrm{C}}=4.06 \mathrm{~Hz}, \mathrm{P}\left(\mathrm{CH}_{3}\right)_{2}\right), 14.71\left(\mathrm{~d},{ }^{1} J_{\mathrm{P}-\mathrm{C}}=4.06 \mathrm{~Hz}, \mathrm{P}\left(\mathrm{CH}_{3}\right)_{2}\right)$, $33.67\left(\mathrm{~s}, \mathrm{C}\left(\mathrm{CH}_{3}\right)_{3}\right), 53.08\left(\mathrm{~s}, \mathrm{C}\left(\mathrm{CH}_{3}\right)_{3}\right), 65.92\left(\mathrm{~d},{ }^{1} J_{\mathrm{P}-\mathrm{C}}=1.92 \mathrm{~Hz}\right.$, $\left.\mathrm{PCH}_{2} \mathrm{~S}\right), 65.94\left(\mathrm{~d},{ }^{1} J_{\mathrm{P}-\mathrm{C}}=1.92 \mathrm{~Hz}, \mathrm{PCH}_{2} \mathrm{~S}\right) ; \delta^{31} \mathrm{P}(202.46 \mathrm{MHz}$; $\left.\mathrm{C}_{6} \mathrm{D}_{6}\right)$ : $-82.69 \mathrm{ppm}\left(\mathrm{s} \mathrm{br}, P\left(\mathrm{CH}_{3}\right)_{2}\right)$.

[Mg $\left.\left\{\mathbf{M e}_{2} \mathbf{P C H}_{2} \mathbf{S}\left(\mathrm{NSiMe}_{3}\right)_{2}\right\}_{2}\right] \mathbf{( 8 )} . \mathbf{2}(0.54 \mathrm{~g}, 0.94 \mathrm{mmol}$, 1.0 eq.) and $\mathrm{MgCl}_{2}(0.13 \mathrm{~g}, 1.4 \mathrm{mmol}, 1.5$ eq.) were combined in an argon drybox and dissolved in thf $(10 \mathrm{~mL})$. After stirring for 
$24 \mathrm{~h}$ at room temperature, the solvent was evaporated in vacuo and the resulting powder was suspended in pentane $(10 \mathrm{~mL})$. The suspension was filtered and reduced in volume. After storing the colourless solution at $4{ }^{\circ} \mathrm{C}$ for four days, crystals suitable for structural analysis were obtained. Yield: $0.53 \mathrm{~g}, 0.90 \mathrm{mmol}, 96 \%$; $\mathrm{mp} 206.5^{\circ} \mathrm{C}$ (from pentane, decomp.); Found C, 36.92; H, 9.27; N, 9.75; $\mathrm{S}, 11.11 . \mathrm{C}_{18} \mathrm{H}_{52} \mathrm{~N}_{4} \mathrm{Si}_{4} \mathrm{P}_{2} \mathrm{~S}_{2} \mathrm{Mg}$ requires $\mathrm{C}, 36.81 ; \mathrm{H}, 8.92 ; \mathrm{N}$, 9.54; $\mathrm{S}, 10.92 \% ; \delta^{1} \mathrm{H}\left(500.13 \mathrm{MHz}, \mathrm{C}_{6} \mathrm{D}_{6}\right): 0.29\left(36 \mathrm{H}, \mathrm{s}, \mathrm{Si}\left(\mathrm{CH}_{3}\right)_{3}\right)$, $0.91\left(12 \mathrm{H}, \mathrm{s}, \mathrm{P}\left(\mathrm{CH}_{3}\right)_{2}\right), 2.398\left(2 \mathrm{H}, \mathrm{d},{ }^{2} J_{\mathrm{P}-\mathrm{H}}=1.93 \mathrm{~Hz}, \mathrm{PCH}_{2} \mathrm{~S}\right)$, $2.402\left(2 \mathrm{H}, \mathrm{d},{ }^{2} J_{\mathrm{P}-\mathrm{H}}=1.93 \mathrm{~Hz}, \mathrm{PCH}_{2} \mathrm{~S}\right) ; \delta^{13} \mathrm{C}\left(125.77 \mathrm{MHz}, \mathrm{C}_{6} \mathrm{D}_{6}\right)$ : $2.75\left(\mathrm{~s}, \mathrm{Si}\left(\mathrm{CH}_{3}\right)_{3}\right), 13.77\left(\mathrm{~d},{ }^{1} J_{\mathrm{P}-\mathrm{C}}=2.30 \mathrm{~Hz}, \mathrm{P}\left(\mathrm{CH}_{3}\right)_{2}\right), 13.79(\mathrm{~d}$, $\left.{ }^{1} J_{\mathrm{P}-\mathrm{C}}=2.30 \mathrm{~Hz}, \mathrm{P}\left(\mathrm{CH}_{3}\right)_{2}\right), 67.57\left(\mathrm{~s}, \mathrm{PCH}_{2} \mathrm{~S}\right) ; \delta^{29} \mathrm{Si}(99.36 \mathrm{MHz}$, $\left.\mathrm{C}_{6} \mathrm{D}_{6}\right):-4.05\left(\mathrm{~s},{ }^{1} J_{\mathrm{N}-\mathrm{Si}}=27.91 \mathrm{~Hz}, \mathrm{Si}\left(\mathrm{CH}_{3}\right)_{3}\right) ; \delta^{31} \mathrm{P}(202.46 \mathrm{MHz}$, $\left.\mathrm{C}_{6} \mathrm{D}_{6}\right):-84.63\left(\mathrm{~s}, \mathrm{PCH}_{2} \mathrm{~S}\right)$.

$\left[\mathbf{P h}_{2} \mathbf{P C H}_{2}\left(\mathbf{S N S i M e}_{3}\right)\left(\mathrm{HNSiMe}_{3}\right)\right]$ (9). To a slurry of $\mathrm{Ph}_{2} \mathrm{PCH}_{2}$ Li.TMEDA ( $0.88 \mathrm{~g}, 2.72 \mathrm{mmol}, 1.0$ eq.) in pentane $(30 \mathrm{~mL}) \mathrm{S}\left(\mathrm{NSiMe}_{3}\right)_{2}(0.56 \mathrm{~g}, 2.72 \mathrm{mmol}, 1.0$ eq.) was slowly added at $-78{ }^{\circ} \mathrm{C}$. After stirring at room temperature overnight, the solution was filtered over celite and the solvent evaporated in vacuo. The precipitate was dissolved in toluene, reduced in volume, layered with pentane and stored at $-25^{\circ} \mathrm{C}$. After 2 months, crystals suitable for structural analysis were obtained. Yield: $1.07 \mathrm{~g}, 2.63 \mathrm{mmol}, 97 \%$; mp $138.3{ }^{\circ} \mathrm{C}$ (from pentane, decomp.); Found: C, 55.94; $\mathrm{H}, 7.66 ; \mathrm{N}, 7.00 ; \mathrm{S}, 8.00 . \mathrm{C}_{19} \mathrm{H}_{31} \mathrm{Si}_{2} \mathrm{~N}_{2} \mathrm{PS}$ requires $\mathrm{C}, 56.11 ; \mathrm{H}, 7.68 ; \mathrm{N}, 6.89 ; \mathrm{S}, 7.88 \% ; \delta{ }^{1} \mathrm{H}\left(500.13 \mathrm{MHz}, \mathrm{C}_{6} \mathrm{D}_{6}\right)$ : $0.22\left(18 \mathrm{H}, \mathrm{s}, \mathrm{Si}\left(\mathrm{CH}_{3}\right)_{3}\right), 4.09\left(2 \mathrm{H}, \mathrm{d},{ }^{2} J_{\mathrm{P}-\mathrm{H}}=0.80 \mathrm{~Hz}, \mathrm{PCH}_{2} \mathrm{~S}\right)$, 7.00-7.04 (2 H, m, $p-\mathrm{H}), 7.06-7.10(4 \mathrm{H}, \mathrm{m}, m-\mathrm{H}), 7.49-7.52$ (2 $\mathrm{H}, \mathrm{m}, o-\mathrm{H}) ; \delta{ }^{13} \mathrm{C}\left(125.76 \mathrm{MHz}, \mathrm{C}_{6} \mathrm{D}_{6}\right): 1.89\left(\mathrm{Si}\left(\mathrm{CH}_{3}\right)_{3}\right), 63.59$ $\left(\mathrm{d},{ }^{1} J_{\mathrm{P}-\mathrm{C}}=24.61 \mathrm{~Hz}, \mathrm{PCH}_{2} \mathrm{~S}\right), 128.76\left(\mathrm{~d},{ }^{3} J_{\mathrm{P}-\mathrm{C}}=6.65 \mathrm{~Hz}, m-\mathrm{C}\right)$, $129.00(p-\mathrm{C}), 133.34\left(\mathrm{~d},{ }^{2} J_{\mathrm{P}-\mathrm{C}}=19.71 \mathrm{~Hz}, o-\mathrm{C}\right), 138.43\left(\mathrm{~d},{ }^{1} J_{\mathrm{P}-\mathrm{C}}=\right.$ $14.76 \mathrm{~Hz}$, ipso-C); $\delta^{31} \mathrm{P}\left(202.46 \mathrm{MHz}, \mathrm{C}_{6} \mathrm{D}_{6}\right):-28.81\left(\mathrm{~s}, P_{2} \mathrm{H}_{2} \mathrm{~S}\right) ; \delta$ ${ }^{29} \mathrm{Si}\left(99.36 \mathrm{MHz}, \mathrm{C}_{6} \mathrm{D}_{6}\right): 2.59\left(\mathrm{~s},{ }^{1} J_{\mathrm{N}-\mathrm{Si}}=28.35 \mathrm{~Hz}\right) ; \mathrm{EI}-\mathrm{MS} m / z: 406$ $\left(\mathrm{M}^{+}, 17 \%\right), 318\left(14, \mathrm{M}-\mathrm{HNSiMe}_{3}\right), 286\left(19, \mathrm{Ph}_{2} \mathrm{PCH}_{2} \mathrm{SNSiMe}_{3}\right)$, $272\left(19, \mathrm{Ph}_{2} \mathrm{PCH}_{2} \mathrm{SiMe}_{3}\right), 207\left(15, \mathrm{M}-\mathrm{Ph}_{2} \mathrm{PCH}_{2}\right), 199$ (100, $\left.\mathrm{Ph}_{2} \mathrm{PCH}_{2}\right), 121\left(44, \mathrm{SN}\left(\mathrm{HSiMe}_{3}\right)+\mathrm{H}\right), 73\left(20, \mathrm{SiMe}_{3}\right)$.

\section{Acknowledgements}

We kindly acknowledge funding from the DFG Priority Program 1178 and the Center of Materials Crystallography. We are grateful for the continuous support from CHEMETALL GmbH, Frankfurt and Langelsheim. S.K.P. and D.S. thank the DFG and INSA for supplying the Indo-German exchange grant.

\section{Notes and references}

1 (a) L. Mahalakshmi and D. Stalke, Struct. Bonding (Berlin), 2002, 103, 3750; (b) F. Baier, Z. Fei, H. Gornitzka, A. Murso, S. Neufeld, M. Pfeiffer, I. Rüdenauer, A. Steiner, T. Stey and D. Stalke, J. Organomet. Chem., 2002, 661, 111; (c) L. H. Gade, Eur. J. Inorg. Chem., 2002, 1257; (d) L. H. Gade, Chem. Commun., 2000, 173; (e) L. H. Gade, Acc. Chem. Res., 2002, 35, 575; (f) L. H. Gade, J. Organomet. Chem., 2002, 661, 85.

2 (a) S. Trofimenko, Prog. Inorg. Chem., 1986, 34, 115; (b) S. Trofimenko, Chem. Rev., 1993, 93, 943.

3 T. Stey, M. Pfeiffer, J. Henn, S. K. Pandey and D. Stalke, Chem. Eur. J., $2007,13,3636$.

4 T. Stey, J. Henn and D. Stalke, Chem. Commun., 2007, 413.

5 J. Henn, K. Meindl, A. Oechsner, G. Schwab, T. Koritsanszky and D. Stalke, Angew. Chem., 2010, 122, 2472, (Angew. Chem., Int. Ed., 2010, 49, 2422).

6 A. Murso and D. Stalke, Z. Anorg. Allg. Chem., 2004, 630, 1025.
7 (a) J. Campora, I. Matas, B. Classen, P. Palma and E. Alvarez, Inorg. Chim. Acta, 2006, 359, 3191; (b) A. M. Bond, R. Colten, F. Marken and J. N. Walter, Organometallics, 1997, 16, 5006.

8 O. Walter, G. Huttner and R. Kern, Z. Naturforsch., B: Sci., 1996, 51, 922.

9 (a) J. Hoyano and L. K. Peterson, Can. J. Chem., 1976, 54, 2697; (b) S. Fischer, J. Hoyano and L. K. Peterson, Can. J. Chem., 1976, 54, 2710.

10 H. W. Roesky, Th. Gries, K. S. Dhathathreyan and H. Lueken, Z. Anorg. Allg. Chem., 1987, 547, 199.

11 W.-H. Leung, Q.-F. Zhang and X.-Y. Yi, Coord. Chem. Rev., 2007, 251, 2266.

12 M. P. Batten, A. J. Canty, K. J. Cavell, T. Rüther, B. W. Skelton and A. H. White, Acta Crystallgr., Sect. C, 2004, 60, m311.

13 (a) C. Kimblin, W. E. Allen and G. Parkin, J. Chem. Soc. Chem. Commun., 1995, 235; (b) T. N. Sorrell, W. E. Allen and P. S. White, Inorg. Chem., 1995, 34, 952; (c) C. Kimblin, B. N. Bridgewater, D. G. Churchill and G. Perkin, J. Chem. Soc. Dalton Trans., 2000, 2191; (d) W. Klaeui, C. Piefer, G. Rheinwald and H. Lang, Eur. J. Inorg. Chem., 2000, 1549; (e) C. Kimblin, V. J. Murphy, T. Hascall, B. M. Bridgewater, J. B. Bonanno and G. Parkin, Inorg. Chem., 2000, 39, 967; (f) P. C. Kunj, G. J. Reiss, W. Frank and W. Kläui, Chem. Eur. J., 2003, 3945; (g) A. Schiller, R. Scopelliti, N. Benmelouka and K. Severin, Inorg. Chem., 2005, 44, 6482 .

14 F. Eymery, P. Burattin, F. Mathey and P. Savignac, Eur. J. Org. Chem., $2000,2045$.

15 R. Huerta, A. Flores-Figueroa, V. A. Ugalde-Saldivar and I. Castillo, Inorg. Chem., 2007, 46, 9510.

16 (a) M. Veith, Chem. Rev., 1990, 90, 3; (b) M. Veith, S. Weidner, K. Kunze, D. Käfer, J. Hans and V. Huch, Coord. Chem. Rev., 1994, 137, 297; (c) P. Braunstein, M. Veith, J. Blin and V. Huch, J. Chem. Soc. Dalton Trans., 1997, 995; (d) M. A. Beswick, M. K. Devis, P. R. Raitby, A. Steiner and D. S. Wright, Chem. Commun., 1996, 2619; (e) A. Steiner and D. Stalke, J. Chem. Soc., Chem. Commun., 1993, 1702; (f) A. Steiner and D. Stalke, Inorg. Chem., 1995, 34, 4846; $(g)$ T. Kottke and D. Stalke, Chem. Ber./Recl., 1997, 130, 1365; (h) M. Veith, C. Ruloff, V. Huch and F. Töllner, Angew. Chem., 1988, 100, 1418, (Angew. Chem., Int. Ed. Engl., 1988, 27, 1381).

17 I. Kuzu, I. Krummenacher, J. Meyer, F. Armbruster and F. Breher, Dalton Trans., 2008, 5836.

18 F. Armbruster, I. Fernandez and F. Breher, Dalton Trans., 2009, 5612.

19 (a) G. C. Welch, R. R. Shan Juan, J. D. Masuda and D. W. Stephan, Science, 2006, 314; (b) G. C. Welch and D. W. Stephan, J. Am. Chem. Soc., 2007, 129, 1880; (c) S. J. Geier and D. W. Stephan, Chem. Commun., 2008, 99.

20 (a) K. Albrecht, V. Kaiser, R. Boese, J. Adams and D. E. Kaufmann, J. Chem. Soc. Perkin Trans. 2, 2000, 2153; (b) T. Agou, J. Kobayashi and T. Kawashima, Org. Lett., 2005, 7, 4373; (c) Z. Liu, Q. Fang, D. Wang, D. Cao, G. Xue, W. Yu and H. Lei, Chem. Eur. J., 2003, 9, 5074.

21 G. Rodríguez, M. Albrecht, T. Schoenmaker, A. Ford, M. Lutz, A. L. Spek and G. von Koten, J. Am. Chem. Soc., 2002, 124, 5127.

22 (a) V. Cesar, S. Bellemin-Laponnaz and L. H. Gade, Chem. Soc. Rev., 2004, 33, 619; (b) L. H. Gade and S. Bellemin-Laponnaz, Coord. Chem. Rev., 2007, 251, 718; (c) M. C. Perry and K. Burgess, Tetrahedron: Asymmetry, 2003, 14, 951.

23 (a) H. Nakai, S. Ogo and Y. Watanabe, Organometallics, 2002, 21, 1674; (b) D. E. Bergbreiter, P. L. Osburn, A. Wilson and E. M. Sink, J. Am. Chem. Soc., 2002, 124, 9058.

24 A. Melaiye, R. S. Simons, A. Milsted, F. Pingitore, C. Wesdemiotis, C. A. Tessier and W. J. Youngs, J. Med. Chem., 2004, 47, 973.

25 R. Fleischer and D. Stalke, J. Organomet. Chem, 1998, 550, 173.

26 (a) J. R. Gardinier, R. M. Silva, C. Gwengo and S. V. Lindeman, Chem. Commun., 2007, 1524; (b) R. M. Silva, C. Gwengo, S. V. Lindeman, M. D. Smith and J. R. Gardinier, Inorg. Chem., 2006, 45, 10998; (c) D. M. Khramov, A. J. Boydston and C. W. Bielawski, Angew. Chem., 2006, 118, 6332, (Angew. Chem. Int. Ed., 2006, 45, 6186); (d) R. Hoffmann, Acc. Chem. Res., 1971, 4, 1; (e) H. Hann, M. Elsmaili and S. A. Johnson, Inorg. Chem., 2006, 45, 7435; $(f)$ R. Raturi, J. Lefèbvre, D. B. Leznoff, B. R. McGarvey and S. A. Johnson, Chem. Eur. J., 2008, 14, 721 .

27 C. Selinka, S. Deuerlein, T. Häuser and D. Stalke, Inorg. Chim. Acta, 2004, 357, 1873 .

28 S. Deuerlein, D. Leusser, U. Flierler, H. Ott and D. Stalke, Organometallics, 2008, 27, 2306. 
29 L. Wang, E. Hauptman, L. K. Johnson, E. F. McCord, Y. Wang and S. D. Ittel, E. I. Du, Pont De Nemours and Company, WO/2001/092342, 2001.

30 P. Rademacher, Strukturen Organischer Moleküle, VCH, New York, 1987.

31 (a) D. Leusser, J. Henn, N. Kocher, B. Engels and D. Stalke, J. Am Chem. Soc., 2004, 126, 1781; (b) J. Henn, D. Ilge, D. Leusser, D. Stalke and B. Engels, J. Phys. Chem. A, 2004, 108, 9442.

32 (a) H. J. Reich and B. Ö. Gudmundsson, J. Am. Chem. Soc., 1996, 118, 6074; (b) W. Clegg, K. Izod, W. McFarlane and P. O'Shaughnessy, Organometallics, 1999, 18, 3950.

33 'Structures of lithium salts of heteroatom compounds', F. Pauer and P. P. Power, in Lithium Chemistry (ed. A.-M. Sapse and P. v. Ragué Schleyer), Wiley Interscience, New York, 1995, p. 295.

34 (a) S. Blair, K. Izod, W. Clegg and R. W. Harrington, Eur. J. Inorg Chem., 2003, 3319; (b) S. Blair, K. Izod and W. Clegg, Inorg. Chem., 2002, 41, 3886; (c) A. Pape, M. Lutz and G. Müller, Angew. Chem., 1994, 106, 2375, (Angew. Chem., Int. Ed. Engl., 1994, 33, 2281); (d) D. E. Gindelberger and J. Arnold, Inorg Chem., 1994, 33, 6293.
35 (a) D. Leusser, B. Walfort and D. Stalke, Angew. Chem., 2002, 114, 2183, (Angew. Chem., Int. Ed., 2002, 41, 2079); (b) B. Walfort and D. Stalke, Angew. Chem., 2001, 113, 3965, (Angew. Chem. Int., Ed., 2001, 40, 3846).

36 O. J. Scherer and R. Wies, Z. Naturforsch., 1970, 25b, 1486.

37 O. J. Scherer and G. Wolmershäuser, Z. Anorg. Allg. Chem., 1977, 432, 173.

38 D. J. Peterson, J. Organomet. Chem., 1967, 8, 199.

39 T. Schulz, K. Meindl, D. Leusser, D. Stern, J. Graf, C. Michaelsen, M. Ruf, G. M. Sheldrick and D. Stalke, J. Appl. Crystallogr., 2009, 42, 885. 40 (a) D. Stalke, Chem. Soc. Rev., 1998, 27, 171; (b) T. Kottke and D. Stalke, J. Appl. Crystallogr., 1993, 26, 615.

41 P. Müller, R. Herbst-Irmer, A. L. Spek, T. R. Schneider and M. R. Sawaya, in Crystal Structure Refinement - A Crystallographer's Guide to SHELXL in IUCr Texts on Crystallography, Vol. 8 (Ed.: P. Müller), Oxford University Press, Oxford (England), 2006.

42 (a) G. M. Sheldrick, Acta Crystallogr., Sect. A: Found. Crystallogr., 2008, 64, 112; (b) G. M. Sheldrick, Acta Crystallogr., Sect. A: Found. Crystallogr., 1990, 46, 467. 